\title{
Foreign Direct Investment Inflows and Labor Productivity in Pakistan: A Sector- Wise Panel Cointegration Analysis
}

\author{
Ayesha Serfraz ${ }^{1}$ \\ 'Doctoral Student at University of Hamburg, Germany. Assistant Professor at University of the Punjab, Lahore, \\ Pakistan \\ Email:ayesha.serfraz@live.com Tel: +92-300-4+426557
}

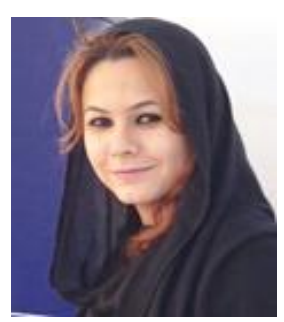

\begin{abstract}
This study empirically analyzes the effects of sector-wise FDI inflows on respective sector-wise labor productivity for a panel of seven major sectors of Pakistan's economy covering time period of 1997-2016. For empirical analysis, sector-wise FDI inflows has been used as an independent variable while sector-wise labor productivity is a dependent variable. Initial tests conclude that LSDV fixed effects model is the most appropriate test for the data being used for empirical analysis. Further tests confirm the existence of a long-run Cointegration between these two variables. Wald test shows that a uni-directional short-run causality exists, running from sectorwise labor productivity to sector-wise FDI inflows. Pair-wise Granger-Causality test further shows that the effects of FDI inflows are not limited to one sector, rather there is an evidence of spillover effect from one sector to an-other. All empirical tests conclude that sector-wise FDI inflows positively affect sector-wise labor productivity in case of Pakistan.
\end{abstract}

Keywords: Sector-wise FDI inflows, Sectors-wise labor productivity, Panel cointegration, Spillovers, Pakistan. JEL Classification: F21, J01, C10.

Citation | Ayesha Serfraz (2018). Foreign Direct Investment Inflows and Labor Productivity in Pakistan: A Sector-Wise Panel Cointegration Analysis. Asian Journal of Economics and Empirical Research, 5(1): 1-18.

History:

Received: 11 January 2018

Revised: 24 January 2018

Accepted: 26 January 2018

Published: 30 Janury 2018

Licensed: This work is licensed under a Creative Commons

Attribution 3.0 License $(\mathrm{oc})$ E E

Publisher:Asian Online Journal Publishing Group

\section{Contents}

1. Introduction

Funding: This study received no specific financial support

Competing Interests: The author declares that there are no conflicts of interests regarding the publication of this paper.

Transparency: The author confirms that the manuscript is an honest, accurate, and transparent account of the study was reported; that no vital features of the study have been omitted; and that any discrepancies from the study as planned have been explained.

Ethical: This study follows all ethical practices during writing.

2. Literature Review

3. Empirical Analysis

...2

...3

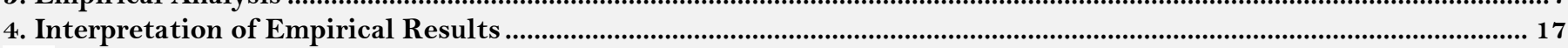

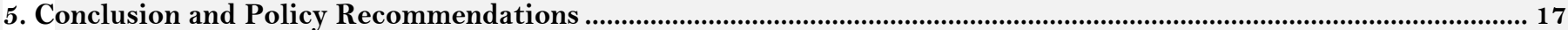

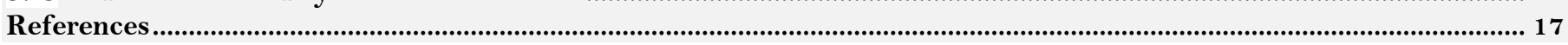




\section{Introduction}

It is generally accepted by researchers that foreign direct investment (FDI) inflows cause positive impact on recipient country by way of boosting economic growth through transfer of better technology, knowledge and skills, training, education opportunities and many more. Further as added by Kurtishi-Kastrati (2013) FDI inflows lead to capacity building of labor and entrepreneurs. In addition, it leads to an improvement in social conditions. Johnson (2005) adds that FDI helps in growth of international trade by flow of goods and capital from one part of the world to the other part. This invariably takes place through MNCs and thus FDI has become an important factor in the process of globalization. Regarding labor productivity, particularly in developing economies, recent debates have resulted in different answers. In some countries FDI inflows do increase labor productivity by providing more technical know- how especially in case of MNCs which are responsible for providing better training, resulting in an increase in wages and that in turn raises standard of living and thus causes an enhancement in labor productivity. This relationship has been discussed theoretically and tested empirically in the recent paper by the same author i.e., Serfraz (2017). On the other hand, labor productivity may fall due to replacement of labor by capital in the form of high technology, especially in case of labor abundant countries, since absorptive capacity of labor serves as a hurdle. MNCs cause wage differentials by hiring the already better trained labor and refining their skills by providing higher training. Also education plays a very important role in increasing labor productivity. Although role of MNCs results in unequal distribution of income and misallocation of resources, but the afore-mentioned advantages cannot be ignored. The extent of productivity growth caused by FDI varies from country to country. Therefore it would be incorrect to claim that FDI inflows do not increase productivity at all. It does increase productivity and growth but not at a uniform level. Pakistan has also benefitted from FDI inflows and presently, it is attracting higher amount of FDI due to liberalization policies. The advantages have been observed in the form of technology transfer, increase in labor productivity, reducing saving-investment gap etc. If the research is narrowed down to analyze the impact of FDI inflows on individual sectors rather than economy as a whole, many studies have argued that FDI inflows benefit individual sectors though not every sector equally. It may be due to the biasedness of foreign investors caused by ease of doing business in a particular sector as compared to the other. Mostly industrial and services sectors attract more FDI inflows as compared to other sectors like agriculture because these two sectors hire more educated and skilled people viz a viz labor force employed in agriculture sector. Consequently it becomes easy for foreign investors to train the already skilled labor.

Overall economic growth of any country is a measure of its level of development but sectoral growth cannot be ignored since sectors of any country are its building blocks and play a vital role in increasing economic growth.

According to Pakistan Bureau of Statistics ${ }^{1}$, the three main sectors of Pakistan's economy are agriculture, industry and services. But these sectors are further divided into sub-sectors like food, mining, trade, transport, construction etc. Majority of discussion related to sectors is confined to these three main sectors. Moreover the relationship between sector-wise FDI inflows with reference to growth of respective sectors does not focus on sector-wise labor productivity. Regarding growth, it has been established in literature that sector-wise FDI inflows increase sector-wise growth especially related to industrial sector.

Pakistan needs to introduce more investment friendly policies, particularly for foreign investors, to increase FDI since more FDI inflows will not only increase the growth of individual sectors but also the overall growth of economy. Many authors (detailed discussion available in literature review) have suggested the same for other developing countries. At the same time, there are controversies related to the impact of FDI inflows on various sectors. There is a lot of discussion about sector-wise FDI inflows and economic growth but not much has been discussed about sector specific labor productivity. Whether, sector-wise FDI inflows increase respective sectorwise labor productivity or not, this is the main innovative point of the present study and is actually an addition to the present knowledge on the subject. This paper is an extension of the previous research carried out by the same author, i.e. Serfraz (2017) in which an empirical analysis has been conducted to analyze short run and long run causality between FDI inflows and labor productivity in Pakistan. Now the main focus is to find out the relationship between sector-wise FDI inflows and related labor productivity for seven major sectors of Pakistan's economy.

A panel of seven sectors has been taken along-with sector specific labor productivity to empirically analyze the relationship. Sector-wise FDI inflows and sector-wise labor productivity data has been used.

Panel unit root tests have been applied. Since panel data tests can be applied as fixed effects, random effects or pooled LSDV model, the empirical part first proves that which test and static panel data model is suitable for the data being used to carry out empirical analysis. After getting confirmed results about type of static panel data model, panel Cointegration tests have been conducted. Therefore, this study does not directly jump to the type of model to be used, but all initial tests have been presented in empirical section and conclusion is drawn on the basis of results. Also empirical section throws light on characteristics of panel data models and as to what are their advantages and disadvantages.

The seven sectors used in this study are:-

1- Agriculture

2- Manufacturing and mining

3- Construction

4- Electricity and gas distribution

5- Transport

6- Trade

7- Others (financing, real estate, business services, extra territorial and other public and private services).

${ }^{1}$ http://www.pbs.gov.pk/content/what-are-major-sectors-economy-pakistan 
For this purpose the data from 1997-2016 has been used. Data prior to 1997 has not been estimated, therefore this puts a limitation on the study.

For each sector, FDI inflows have been estimated along-with the labor specific to the sector. The details of data are also mentioned in coming chapters of the paper.

This paper is divided into four main sections. Section 1 explains the introduction and objective of study. Section 2 throws light on literature review with sub-sections dealing with available literature, both national and international studies, relating to the topic under discussion. Also, it highlights the gaps in existing body of knowledge and contribution made by present study. Detailed empirical analysis has been presented in section 3 with sub-sections explaining different steps, empirical tests and their interpretations. Last section concludes the study along-with policy recommendations.

\subsection{Contribution and Objective of the Study}

After establishing a positive relationship between FDI inflows and labor productivity in case of Pakistan in the previous paper (Serfraz, 2017) this study, instead of analyzing FDI's impact on the growth of different sectors of Pakistan's economy, aims at examining the sector-wise FDI inflow and its effect on respective sector-wise labor productivity in Pakistan. For this purpose, seven major sectors have been taken along-with the data of labor force hired in those particular sectors.

Whereas majority of the studies have concentrated on the relationship between sector-wise FDI inflows and growth, the unique contribution of this study in the existing literature is that it analyzes the relationship between each sector's FDI inflows and its corresponding impact on labor productivity. Furthermore, this study is one of the very few studies which has investigated the relationship between FDI and respective labor productivity of 'seven' major sectors of Pakistan's economy for empirical analysis instead of empirically analyzing 'growth' of two or three sectors. The reason behind taking these seven sectors and not more, is due to the limitation on availability of data. Those sectors have been included for which data is available for all the years (1997-2016).

\section{Literature Review}

Literature review is divided into three sections. Section 1 deals with the relevant literature on the topic available in international studies. Also the established relationships of individual sectors will be discussed in detail since the available literature has used different sectors for analyzing the relationship. In section 2 , studies related to Pakistan will be analyzed. Section 3 sums up the literature explaining the gaps which will be filled by the present study.

\subsection{International Studies}

Maathai and Sahoo (2008) carried out an empirical analysis to examine the effects of FDI inflows to nine major sectors of India using panel Cointegration approach covering time period from 1991-92 to 2004-05. Their empirical findings suggested a positive impact of FDI inflows on output, labor productivity and exports on drugs and pharmaceuticals sectors. In case of transport and metallurgical sectors, FDI inflows and labor productivity revealed a positive Cointegration whereas FDI inflows did not show a positive impact on labor-intensive sectors like transport and chemicals due to backwardness of labor. Their overall conclusion showed a negative impact on labor productivity and an increase in FDI inflows did not reveal any positive impact on Indian economy at the sectoral level both in terms of output and labor productivity.

Dürnel (2012) empirically investigated the effects of FDI inflows on ten individual sectors of Turkish economy. Using panel Cointegration and Granger-Causality test for the time period of 2000-2009, the study concluded that FDI inflows seemed to benefit growth rate mostly in the Manufacturing, Electricity, Gas and Water, Wholesale and Retail Trade sectors. The essential findings of the study suggested that Foreign Direct Investment contributed towards overall growth rate of Turkish economy. The results indicated that though all the sectors were not benefitting from FDI inflows equally but, it was found that FDI inflows increased labor productivity which resulted in an increase in sectoral growth at different levels and to various extents.

Bang et al. (2007) Carried out an empirical analysis to study the impact of FDI inflows on economic growth of China and Vietnam, using sectoral data of China from 1997-2004 and 1995-2003 for Vietnam. The results revealed that though FDI directly showed a significant and positive effect on economic growth as well as through its interaction with labor productivity in both countries, but, the impact was not evenly distributed across sectors. In both the countries, the industrial sector seemed to be the only sector to consistently benefit from FDI inflows as compared to other sectors.

According to Alam et al. (2008) Eastern European countries and Former Soviet union have observed high economic growth in recent years due to increased level of investment. According to the author, productivity growth is the most important factor for increasing overall economic growth. An increase in productivity leads to an increase in profits and consequent investment. Resultantly, wages grow upwards, leading to an increase in standard of living which enhances labor productivity. As a result, the sectors which receive higher investment also have more productive labor force. Author focuses on three main sectors of economy, i.e., agriculture, manufacturing and services. The allocation of resources to relevant sectors directly affects sector-wise productivity and the labor attached to that sector. Due to increase in investment in a particular sector leads to transfer of labor from less productive sector (agriculture) towards more productive sectors (manufacturing and services). At the same time, labor moving to more productive sectors also showed an increase in productivity relevant to that sector.

From this study it can be inferred that labor productivity cannot be determined in isolation, rather sectoral productivity and labor productivity are related and dependent on each other.

Same conclusion has been derived in a study conducted by Mallick (2015). Author carried out an empirical analysis for examining the structural changes and effects of globalization in the form of FDI inflows and economic integration, on labor productivity growth in BRICS countries using shift-share analysis, dynamic panel data method and input-output tables covering the time period of 1990-91 to 2011-12. The empirical findings suggested a high labor productivity growth in BRICS due to globalization and economic integration policies. FDI inflows 
resulted in a two way causality, i.e., FDI inflows affect labor productivity and in turn labor productivity increases sectoral growth resulting in reallocation of labor towards more productive sectors. In addition, the results also suggested that due to FDI inflows, labor is shifting to non-agriculture sectors in case of India and China, and towards services sector in Brazil, Russia and South Africa.

Ilboudo (2014) tested the hypothesis that Solow Residual or TFP can be targeted to increase sectoral growth for mining sector of Chile. Highlighting the importance, author mentions that the mining sector of Chile is one of the most important sectors of Chilean economy and almost one-third of government income comes from copper exports. Using Cobb-Douglas production function, the study revealed a long run relationship between FDI inflows and labor productivity for mining sector of Chile.

Vu and Noy (2009) conducted an empirical study using sector-wise data for a group of six member countries of OECD. They analyzed the relationship between sector-specific impacts of FDI on growth in developed economies. Using cross-country regression, they found that the impact of FDI inflows may be positive or negative depending on direct impact on economy or through an increase in labor productivity. Also different results were obtained across countries and sectors. For some sectors, there was a positive relation and for others it was negative; real estate and financial sector showed a negative but significant effect. Only mining and quarrying showed positive and significant results. In the end, they suggested that FDI in certain sectors is more productive and has high labor productivity and the level of productivity differs across sectors.

Msuya (2007) examined the impact of FDI inflows on agricultural sector of Tanzania. The qualitative study by author suggests that the crops produced by small farmers organized in small holders set-ups attract more FDI as compared to others. Labor productivity depends on many macroeconomic variables including investment regulatory frameworks, policies that promote macroeconomic stability, and improved physical infrastructure. In addition author recommended that creation of 'strong bonds' between small holders and investors through more integration, would help in attracting more FDI inflows to agricultural sector but this should be extended to developing strong institutions in all sectors. This would lead to more FDI inflows which would further increase the productivity and reduction in poverty.

Moving on to industrial sector, Fillat and Woerz (2011) conducted an empirical analysis for examining the impact of FDI on output and productivity using industrial level data for a panel of 35 OECD, Asian and Eastern European countries. Their study concluded that FDI inflows lead to higher labor productivity and output in industrial sector of 'catching-up' or developing countries as compared to developed countries but the productivity differs across industries. Therefore such policies must be devised which can attract more FDI especially in those industries where labor is more productive as it would lead to a higher output.

Bijsterbosch and Kolasa (2010) carried out an empirical analysis for investigating the effect of FDI inflows on productivity by using industrial level data of Central and Eastern European countries. Their findings suggested that FDI leads to increase in productivity both at country and industrial sector level but it depends on area and absorptive capacity. If labor is more efficient and productive, the absorptive capacity results in more benefits from FDI inflows. They also found the evidence that level of labor productivity or human capital is positively associated with a larger impact of FDI though labor productivity levels have throughout remained depressed outside the euro area as compared to the euro area. In the year 2006, the output of industry was almost one-third of the euro area. The productivity level in services sector was almost half of the euro area while the pattern varied across the countries in the sector of construction.

Azeroual (2016) undertook an empirical analysis for examining the impacts of FDI inflows from France and Spain on the TFP of manufacturing sector of Morocco. Author used GMM system in dynamic panels for a subset of 22 branches of this sector between 1985 and 2012 and found that the impact varied depending on the source from which the FDI originated. The impact on TFP from French FDI was negative, and significant, in medium and high level technology industries while the impact of Spanish FDI was significantly positive. The negative impact of French FDI could be attributed to (i) productivity gap between Moroccan and French companies due to high difference in labor productivity and efficiency (ii) the investment rate and control on technology transfer in the hands of French investors. FDI from Spain seemed significant and positive on TFP though the positive impact was weak. French participation, being mostly concentrated in medium and high technology sectors, ranging between 30 percent of foreign ownership, and sometimes going above 70 percent in the case of automotive industry and transport equipment manufacturing.

Morrar and Gallouj (2016) in their empirical study examined the main factors which contribute to growth in services sector of Palestine. The results of panel data analysis suggested a positive and significant effect of FDI on the labor productivity growth while capital intensive service sectors exercised greater influence on labor productivity growth. Other public services like retail trade, the sale and repair of motor vehicles and land transport are on weaker growth trajectory. The political instability adds fuel to the fire by further affecting the productivity growth of services sector. The author recommends that government should concentrate on policies which create new jobs for those thousands who lost their jobs inside Israel along-with increasing productivity of its unskilled workers.

Alam et al. (2013) conducted an empirical analysis to examine the causality between economic growth, FDI inflows and labor productivity using a panel of 19 OECD member countries for the time period of 1980-2009. The results suggested the evidence of causality but after 1995, the policies favored in shifting FDI inflows towards manufacturing and services sectors where technological spillovers were high due to higher labor productivity in these sectors which resulted in both short run and long run causality.

Mallick (2013) argues that due to globalization, advancement in technology and factor of competition, the demand for productive labor is increasing since skilled and productive labor in every economic sector leads to an overall economic growth. For empirically analyzing this relationship, author conducted an analysis using panel estimation on data extracted from OECD and WDI covering time period from 1990-91 to 2011-12. The results of multiple regression also suggested that the indicators of globalization like FDI inflows and openness of economy have positive and significant impact on labor productivity both in individual sectors and economy as a whole. 
Kirti and Prasad (2016) studied the impact of FDI inflows on Indian economy taking both sectoral analysis and combined effect together. The OLS estimation results revealed that FDI has both positive and negative effects on sectors and economy. They found that FDI leads to unemployment due to the use of capital intensive technology which replaces labor. Regarding sector-wise analysis, they suggested that if capital intensive technology is used in agricultural sector (most backward sector of economy), this will lead to an increase in output based on high labor productivity due to spillover effects from technology transfer. However, manufacturing and services sectors are attracting more FDI due to high labor productivity in the respective sectors.

Thangavelu et al. (2015) analyzed the impacts of trade on labor productivity of services sector for five ASEAN countries-Indonesia, Malaysia, the Philippines, Singapore, and Thailand. They used fixed effects and GMM estimators for the time period of 1990-2005. Four subsectors have been used for empirical analysis, i.e., (i) wholesale, retail, and hotel; (ii) transport, storage, and communications; (iii) finance, insurance, and real estate; and (iv) community, social, and personal sectors. The results show that the more exposure to exports leads to an increase in labor productivity in all these five countries. Furthermore, higher FDI inflows lead to increase in productivity and output of services sector which then provides inputs for manufacturing sector in the region. Therefore author suggests that such policies must be adopted which would lead to more openness and exposure to foreign investment for the advancement of services sector since it supports manufacturing sector as well. Their results also highlight that increase in labor productivity and mobility of skilled labor will lead to an increase in services sector to the overall growth of both domestic and regional economies.

Thuy (2007) investigated the effects of FDI inflows on industrial sector of Vietnam using industry level panel data for 29 industrial sectors during the periods of 1995-1999 and 2000-2002. The author also made an attempt to estimate the extent to which FDI inflows generate spillover effects on industrial sector. The empirical results revealed that FDI inflows lead to reduction in government budget deficit, increased exports and employment opportunities and have a positive impact on industrial growth and productivity. The results also indicate that FDI inflows lead to an increase in industrial labor productivity in the form of spillover effects.

Contessi and Weinberger (2009) in their study analyzed the empirical literature on the studies analyzing the relationship between FDI, productivity and growth. Their main emphasis was on studies that used aggregate data and focused on finding the answers of two questions: Is there evidence of a positive relationship between foreign direct investment and national growth? And does the output of the "multinational sectors" exhibit higher labor productivity? According to authors, the available literature provides ambiguous results but majority of studies have concluded that MNCs and FDI inflows lead to increase in labor productivity, wages and employment. These results are specifically true if compared with domestic firms who do not have enough resources to provide better opportunities to domestic labor, FDI not only increases labor productivity but also makes use of human capital by providing more employment opportunities and higher wage rate which leads to sectoral and overall economic growth.

This section of literature review has some important implications. First, all studies agree that FDI inflows and openness lead to increase in labor productivity and sectoral growth. Also an important point to highlight is that, not all sectors enjoy same level of benefits. In most of the studies, agricultural sector has been given less importance due to its backwardness and low return. Industrial and services sectors show better performance and attract more FDI because of higher return as well as availability of skilled and productive labor force working in these sectors. Basically there is a bi-directional causality. FDI leads to increase in sectoral productivity along-with the increase in labor productivity of respective sectors which in turn attracts more FDI inflows.

\subsection{Studies Related to Pakistan}

This section reviews studies relevant to Pakistan, including studies relating to Asian countries or a panel of such countries inclusive of Pakistan, though majority of the studies focus on impact of FDI inflows on sectoral growth rather than sectoral labor productivity.

Ullah et al. (2012) empirically analyzed the role of FDI inflows using data of agriculture and industrial sectors of Pakistan for the time period of 1979-2009. Services sector was also incorporated as an independent variable in the equations of agricultural and industrial sectors. The results of two stage least square (2SLS) suggested a negative impact on agriculture sector and a positive impact on industrial sector. Their results also suggested that an increase in growth rate of agriculture and industrial sector leads to a higher growth of services sector. Consequently employment increases which causes an inclination towards attaining more education. This facilitates availability of increased number of educated and skilled workers which leads to enhancement in labor productivity both at sectoral and macro level. As a result, economic growth picks up.

Khan and Khan (2011) are of the view that although Pakistan has great potential for attracting FDI inflows, but it has not been successful in attracting sufficient amounts due to ineffective institutional framework, poor law and order situation and low labor productivity. Their empirical analysis basically focuses on testing the impact of sector-wise FDI inflows on growth and output using data of Pakistan from 1981-2008. The panel Cointegration and Granger- Causality results suggested that although sectoral FDI inflow increases output and growth of three major sectors i.e., agriculture, industry and services but it is not satisfactory due to above mentioned factors.

Kasi and Zafar (2016) examined the productivity and spillover effects of FDI inflows in four member countries of SAARC including Bangladesh, India, Nepal and Pakistan for the period of 1990-2013. Authors used 3 main sectors for analysis, i.e., primary, manufacturing and services and applied Fully Modified Least Square technique. According to their results, although FDI inflows have positive and significant impact on productivity of all sectors but the effect varies across sectors. They found that maximum productivity effect of FDI is found in services sector through spillover effects where FDI plays an important role and increases labor productivity through technology, training and education.

Majority of studies argue that Pakistan has high potential for attracting FDI inflows but there are many factors which are acting as a hurdle and low labor productivity is one of the most important factors. This is applicable not only at sectoral level but as a whole, as Khan (2011) states, 
'On the whole, Pakistan has a lot of potential to attract foreign investment. Although the rising trend of FDI in various sectors reflects the success of policy; however, FDI inflows are considerably hindered by institutional weakness, corruption, ineffective legal institutions, political uncertainty, poor laws, weak regulatory systems, deteriorating law and order situation, labour productivity and unsustainable international political relations.' (Page 20)

Sahoo (2006) carried out empirical analysis to examine the impact of FDI inflows and its determinants on growth of five South Asia countries including India, Pakistan, Bangladesh, Sri Lanka and Nepal. According to the author, since these countries have been following liberalization policies to attract FDI, all benefitted from FDI but Pakistan is at the bottom of the list. FDI inflows in South Asian countries is basically concentrated in manufacturing and services sectors. The panel Cointegration analysis suggested that market size, labor for growth, infrastructure index and trade openness are main determinants of FDI inflows in these countries. Regarding low benefits from FDI inflows to Pakistan, author points out that major reason is poor labor laws which result in low labor productivity even in those sectors which are attracting high FDI inflows. In addition, Pakistan has a 'decent' FDI policy but low labor productivity is acting as a hurdle in both attracting and benefitting from FDI inflows.

Suleman and Amin (2015) in their study examined the impact of sectoral FDI inflows on industrial growth of Pakistan. They used Cobb-Douglas production function for three sectors of Pakistan's economy including manufacturing, construction, mining and quarrying by using panel Cointegration analysis covering the time period of 1997-2011. Their empirical results suggested that sectoral FDI, capital and labor productivity affect industrial growth of Pakistan both positively and significantly. Authors recommended that such policies should be devised which provide better standard of living, reduce poverty and unemployment in order to increase labor productivity.

Regarding FDI inflows and TFP in Pakistan (Adnan et al., 2017) used Johansen Cointegration analysis and found a positive and significant impact of FDI in Pakistan during long run time period. Domestic factor of production or labor is affected due to low productivity. Their findings suggest that labor needs more attention in the form of increase in education expenditure, better standard of living and high productive capacity.

Here authors started with TFP in Pakistan but ended up at labor productivity since its abundance and importance cannot be ignored.

Park and Shin (2012) studied services sector of 12 major Asian economies including Pakistan. Authors mainly focused on examining that whether services sector can become new engine of growth for developing Asia based on high labor productivity in services sector. Authors added that since services sector had already contributed to Asian economies in past, the panel Cointegration analysis suggested that services sector (as compared to other sectors) has future potential to increase GDP growth of these countries since FDI inflows to services sector is positively affecting the labor productivity of this sector, consequently employment opportunities are increasing. In addition, it was found that labor productivity in services sector is increasing at a high rate in Asian economies, and in case of Pakistan the performance of services sector is on higher trajectory due to which it has become the strongest sector of the economy since the labor productivity has direct and positive relationship with FDI inflows to this sector.

Slimane et al. (2013) empirically examined the direct and indirect impact of FDI inflows on food security for 63 developing economies including Pakistan. For empirical analysis, they used Cobb-Douglas agriculture production function and covered the time period from 1995-2009. Their empirical results did not suggest a direct significant effect of sectoral FDI on food security but a significant and positive indirect impact was found for FDI in agriculture and secondary sector through the growth of agriculture production but it did not show any impact on mining. Negative effects in tertiary sector were observed through FDI inflows. Their results also suggested that secondary sector benefitted through high employment and wage rate which increased labor productivity. Spillover effects were observed in agriculture food security and labor productivity through transfer of technology and knowledge spillovers.

Yusuf (2013) discussed whether Chinese FDI would accelerate Pakistan's growth and argued that Chinese FDI would have positive impacts if China began off-shoring more of its labor-intensive manufacturing activities, Pakistan's textile, leather, white goods and auto industries. Pakistan has been facing problems in benefitting from FDI inflows due to technological backwardness and low labor productivity. Although there is a high potential since it has large number of urban centers but poor investment policies and low factor productivity are main hindrances. Labor laws need to be implemented so that technological spillovers can be enjoyed in manufacturing and export producing sectors. Labor productivity in growth increasing sectors needs attention since Pakistan can gain more from FDI inflows if proper investment is made in modern sectors specially manufacturing and export producing industries.

This section of literature shows that undoubtedly policy makers and researchers have consensus that in general FDI inflows increase labor productivity. Moreover agriculture sector is the most backward sector compared to manufacturing and services sectors. Yet the discussion mainly concentrates on sector-wise FDI inflows and sectoral growth or overall growth instead of labor productivity of each sector.

The empirical part of this paper is aimed at concentrating on the impact of sector-wise FDI on respective sector-wise labor productivity.

Some important figures related to country-wise and sector-wise FDI inflows to Pakistan have been shown in following tables:- 
Table-1. Country Wise FDI Inflows (\$ Million)

\begin{tabular}{|c|c|c|c|c|c|c|c|c|c|c|}
\hline Country & $\begin{array}{l}\text { 2007- } \\
08\end{array}$ & \begin{tabular}{|l}
$2008-$ \\
09
\end{tabular} & \begin{tabular}{|l|}
$2009-$ \\
10 \\
\end{tabular} & \begin{tabular}{|l}
$2010-$ \\
11
\end{tabular} & \begin{tabular}{|l}
$2011-$ \\
12
\end{tabular} & \begin{tabular}{|l|}
$2012-$ \\
13
\end{tabular} & \begin{tabular}{|l|}
$2013-$ \\
14
\end{tabular} & \begin{tabular}{|l|}
$2014-$ \\
15 \\
\end{tabular} & \begin{tabular}{|l|}
$2015-$ \\
16 \\
\end{tabular} & $\begin{array}{l}\text { 2016-17 } \\
\text { (Jul-May) }\end{array}$ \\
\hline USA & $1,309.3$ & 869.9 & 468.3 & 238.1 & 227.7 & 227.1 & 212.1 & 208.9 & 40.5 & 40.8 \\
\hline UK & 460.2 & 263.4 & 294.6 & 207.1 & 205.8 & 633.0 & 157.0 & 169.6 & 138.4 & 54.2 \\
\hline U.A.E & 589.2 & 178.1 & 242.7 & 284.2 & 36.6 & 22.5 & $(47.1)$ & 218.8 & 138.6 & 51.2 \\
\hline Japan & 131.2 & 74.3 & 26.8 & 3.2 & 29.7 & 30.1 & 30.1 & 71.1 & 35.2 & 42.0 \\
\hline Hong Kong & 339.8 & 156.1 & 9.9 & 125.6 & 80.3 & 242.6 & 228.5 & 136.2 & 119.5 & 10.1 \\
\hline Switzerland & 169.3 & 227.3 & 170.6 & 110.5 & 127.1 & 149.0 & 209.8 & 3.2 & 53.4 & 15.9 \\
\hline Saudi Arabia & 46.2 & $(92.3)$ & $(133.8)$ & 6.5 & $(79.9)$ & 3.2 & $(40.1)$ & $(64.8)$ & 24.0 & 1.9 \\
\hline Germany & 69.6 & 76.9 & 53.0 & 21.2 & 27.2 & 5.5 & $(5.7)$ & $(20.3)$ & $(11.6)$ & $(6.1)$ \\
\hline Korea (South) & 1.2 & 2.3 & 2.3 & 7.7 & 25.4 & 25.8 & 24.4 & 14.3 & $(2.3)$ & 7.3 \\
\hline Norway & 274.9 & 101.1 & 0.4 & $(48.0)$ & $(275.0)$ & $(258.4)$ & $(21.6)$ & 2.7 & 172.5 & $(12.6)$ \\
\hline China & 13.7 & $(101.4)$ & $(3.6)$ & 47.4 & 126.1 & 90.6 & 695.8 & 256.8 & 626.2 & 878.8 \\
\hline Others & $2,005.2$ & $1,964.2$ & $1,019.6$ & 631.3 & 289.7 & 285.5 & 255.4 & $(73.6)$ & 566.8 & 944.5 \\
\hline Total including Pvt. Proceeds & $5,409.8$ & $3,719.9$ & $2,150.8$ & $1,634.8$ & 820.7 & $1,456.5$ & $1,698.6$ & 922.9 & $1,901.2$ & $2,028.0$ \\
\hline Privatisation Proceeds & 133.2 & 0.0 & 0.0 & 0.0 & 0.0 & 0.0 & 0.0 & 0.0 & 0.0 & 0.0 \\
\hline FDI Excluding Pvt. Proceeds & $5,276.6$ & $3,719.9$ & $2,150.8$ & $1,634.8$ & 820.7 & $1,456.5$ & $1,698.6$ & 922.9 & $1,901.2$ & $2,028.0$ \\
\hline
\end{tabular}

Source: Board of Investment, Pakistan http://boi.gov.pl/ForeignInvestmentinPakistan.asp $x$

Note: Pakistan's Fiscal Year runs from 1st July till 30th June. The figures in brackets are in negative.

Table-2. Sector Wise FDI Inflows (\$ Million)

\begin{tabular}{|c|c|c|c|c|c|c|c|c|c|c|}
\hline Sectors & $\begin{array}{l}2007- \\
08\end{array}$ & $\begin{array}{l}2008- \\
09\end{array}$ & $\begin{array}{l}2009- \\
10\end{array}$ & $\begin{array}{l}2010- \\
11\end{array}$ & $\begin{array}{l}2011- \\
12\end{array}$ & \begin{tabular}{|l}
$2012-$ \\
13
\end{tabular} & \begin{tabular}{|l|}
$2013-$ \\
14
\end{tabular} & $\begin{array}{l}2014- \\
15\end{array}$ & $\begin{array}{l}2015- \\
16\end{array}$ & $\begin{array}{l}\text { 2016-17 } \\
\text { (Jul May) }\end{array}$ \\
\hline Oil \& Gas & 634.8 & 775.0 & 740.6 & 512.2 & 629.4 & 559.6 & 502.0 & 299.0 & 248.9 & 135.6 \\
\hline Financial Business & $1,864.9$ & 707.4 & 163.0 & 310.1 & 64.4 & 314.2 & 192.8 & 256.4 & 289.0 & 62.8 \\
\hline Textiles & 30.1 & 36.9 & 27.8 & 25.3 & 29.8 & 10.0 & $(0.2)$ & 43.9 & 20.0 & 14.1 \\
\hline Trade & 175.9 & 166.6 & 117.0 & 53.0 & 25.3 & 5.7 & $(3.2)$ & 50.0 & 26.8 & 28.1 \\
\hline Construction & 89.0 & 93.4 & 101.6 & 61.1 & 72.1 & 46.0 & 28.8 & 53.5 & 36.8 & 418.2 \\
\hline Power & 70.3 & 130.6 & $(120.6)$ & 155.8 & $(84.9)$ & 28.4 & 71.4 & 219.3 & 751.3 & 548.0 \\
\hline Chemicals & 79.3 & 74.3 & 112.1 & 30.5 & 96.3 & 71.6 & 94.9 & 55.3 & 88.5 & 10.6 \\
\hline Transport & 74.2 & 93.2 & 132.0 & 104.6 & 18.7 & 44.1 & 2.7 & 6.2 & 70.1 & 38.1 \\
\hline Communication (IT\&Telecom) & $1,626.8$ & 879.1 & 291.0 & $(34.1)$ & $(312.6)$ & $(385.7)$ & 434.2 & 45.1 & 236.8 & 20.0 \\
\hline Others & 764.5 & 763.4 & 586.3 & 416.3 & 282.2 & 765.5 & 375.2 & $105.8)$ & 133.0 & 752.5 \\
\hline $\begin{array}{lll}\text { Total } & \text { including } & \text { Pvt. } \\
\text { Proceeds } & & \\
\end{array}$ & $5,409.8$ & $3,719.9$ & $2,150.8$ & $1,634.8$ & 820.7 & $1,456.5$ & $1,698.6$ & 922.9 & 1901.2 & $2,028.0$ \\
\hline $\begin{array}{l}\text { Privatisation } \\
\text { Proceeds }\end{array}$ & 133.2 & 0.0 & 0.0 & 0.0 & 0.0 & 0.0 & 0.0 & 0.0 & 0.0 & 0.0 \\
\hline FDI Excluding Pvt. Proceeds & $5,276.6$ & $3,719.9$ & $2,150.8$ & $1,634.8$ & 820.7 & $1,456.5$ & $1,698.6$ & 922.9 & 1901.2 & $2,028.0$ \\
\hline
\end{tabular}

Source: Board of Investment, Pakistan http://boi.gov.pk/ForeignInvestmentinPakistan.aspx

$22.6 \%$ increase in Net FDI in July-May, 2016-17 as compared to July-May, 2015-16.

Note: Pakistan's Fiscal Year runs from 1st July till 30th June. The figures in brackets are in negative.

\subsection{Summary of Literature Review and Gaps to be filled by Present Study}

Numerous studies (national and international) have been discussed in literature review. The international literature has thrown light on the relationship between sector-wise FDI inflows and sector-wise labor productivity concluding that sector-wise FDI inflows do increase sector-wise labor productivity especially in case of manufacturing and services sectors. Generally they are in the form of technology transfer, innovation, R \& D and increase in labor productivity but agriculture and related sectors show either no impact or negative because of backwardness and low labor productivity. In case of Pakistan, most of the studies have emphasized on 'growth' instead of labor productivity. Moreover, the literature has also given a hint that spillovers may exist, i.e., FDI inflows to one sector may lead to an increase in labor productivity in one or more sectors like in case of developing economies such as Pakistan, agricultural output affects industrial output or productivity providing inputs for industrial sector (textile sector is the main sector which is affected by agricultural output).

This study aims to fill the gap by empirically analyzing the impact of sector-wise FDI inflows on sector-wise labor productivity. It also tests the spillover effects empirically through Granger- Causality test.

\section{Empirical Analysis}

The empirical part is divided into three sections. Section 1 deals with data details, empirical model and hypothesis. Section 2 shows result of unit root tests. Section 3 is a detailed analysis of panel data models. All panel data models have been applied in order to know that which static panel model suits best to the data being used for this study. The purpose of detailed analysis is to substantiate the relevance of the model applicable for empirical analysis rather than jumping directly to the empirical model itself. Also, the empirical rationale is shown as to which test is pragmatic and what assumptions it holds. In the end, section 4 shows pair-wise Granger-Causality test to see the spillover effects from one sector to another. Section 5 provides a complete interpretation of empirical results.

\section{SECTION-}

\section{1) Data Details and Sources}

- $\quad$ Data for FDI inflows has been extracted from World Development Indicators (WDI), World Bank. UNIT $=$ Current BOP US Dollars 
Data for Sector-wise FDI inflows has been taken from Handbook of Statistics on Pakistan, Chapters 1-2, State Bank of Pakistan and Pakistan Economic Survey (Various issues).

UNIT $=$ Percentage

Data for sector-wise FDI inflows has been constructed by carrying out various steps. It is represented as value added per hour for each sector. Data for total labor force is taken from WDI. Distribution of employed persons of 10 years and above by major industries has been taken from Pakistan Economic Survey 20 1415 and 2015-16 (chapter 12).

UNITS = Value added per hour (Million Dollars)

Data for sector-wise FDI inflows has been taken from Board of Investment (BOI), Pakistan.

\section{UNITS = Million Dollars}

Following abbreviations have been used for presenting data

$\begin{array}{ll}\text { FDI } & =\text { FDI Inflows } \\ \text { LPROD } & =\text { Labor Productivity } \\ \text { AGRI } & =\text { Agriculture } \\ \text { MANUF } & =\text { Manufacturing } \\ \text { CONST } & =\text { Construction } \\ \text { E \& G } & =\text { Electricity and Gas } \\ \text { TRANS } & =\text { Transport } \\ \text { TRADE } & =\text { Trade } \\ \text { OTHERS } & =\text { Others }\end{array}$

Following abbreviations have been used for presenting empirical tests

LLU = Levin, Lin \& Chu.

IPS $=$ Im, Pearon \& Shin.

LSDV = Least Square Dummy Variable.

\section{2) Model and Hypothesis}

Model: Sector-wise FDI inflows increase Sector-wise LPROD

Hypothesis: Relationship between Sector-wise FDI Inflows and Sector-wise LPROD

For this purpose panel models have been applied using seven sectors and their respective labor productivity of Pakistan covering time period of 1997-2016. In all cases LPROD is the dependent variable and INFLOW is the independent variable since the aim is to check whether FDI inflows to each sector increase respective labor productivity or not.

\section{3) Empirical Equation:-}

$y i t=f(x i t)+\mathcal{E}$ it

Where $\mathcal{E}$ it $=$ error term

(To check robustness of results, the model has also been tested other way round)

In case of Wald test and Granger-Causality test, variables get automatically inter-changed to check bidirectional causality. Also, Granger-Causality test has been applied to empirically check the spillover effects.

The empirical section does not directly jump to panel model, rather all initial steps have been conducted and presented to confirm the reliability of the model for panel data.

All tests are applied in EVIEWS 9.0.

\section{SECTION- 2}

\section{1) Panel Unit Root Tests}

First step in any empirical study is to check the stationarity status of data. Depending on that, further tests are applied. Initially all series have been presented in graphical form and then results are presented in tabular form. For this purpose, two famous tests are applied for checking unit root, i.e. LLC and IPS. Results and interpretation are presented in Table-3.

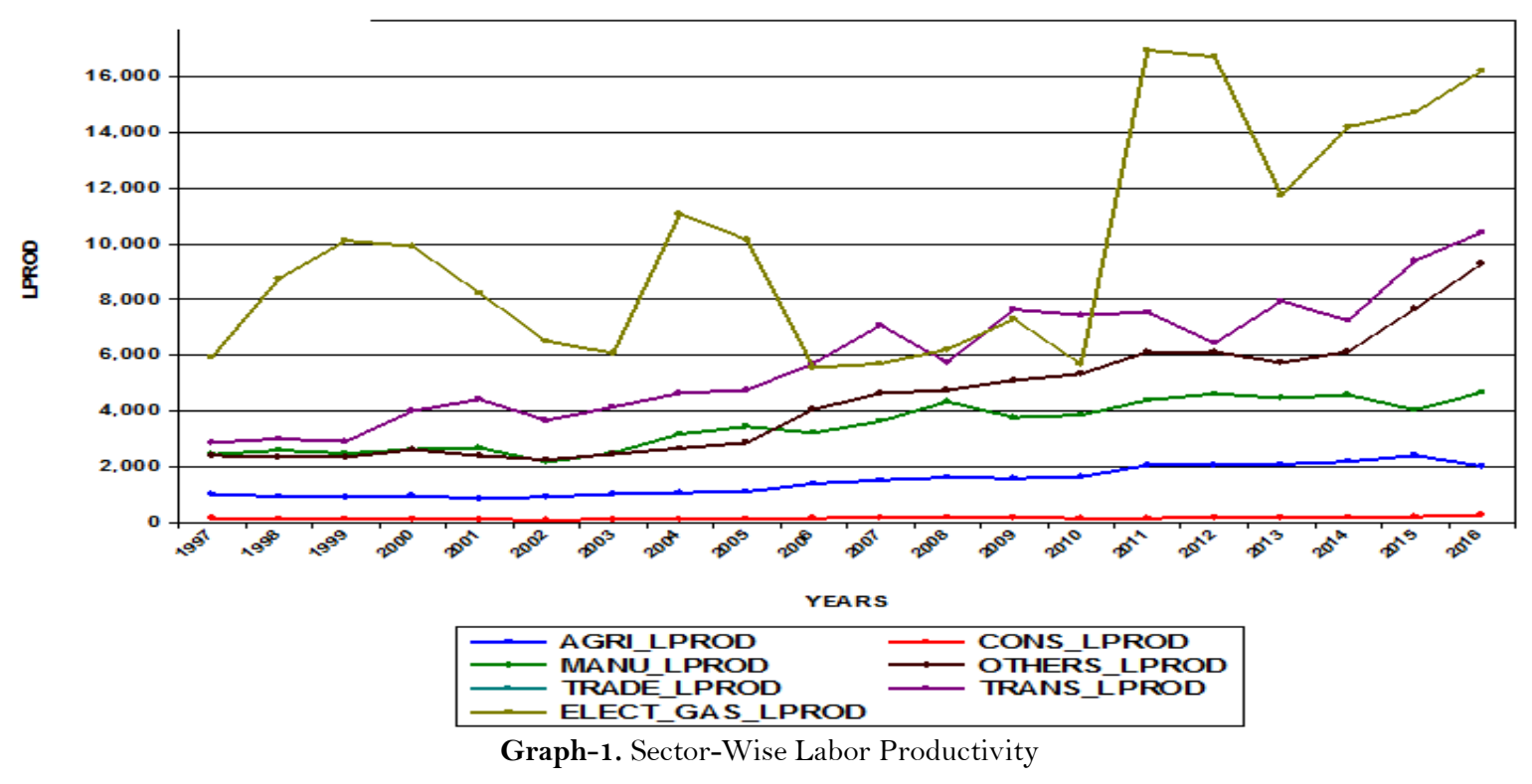




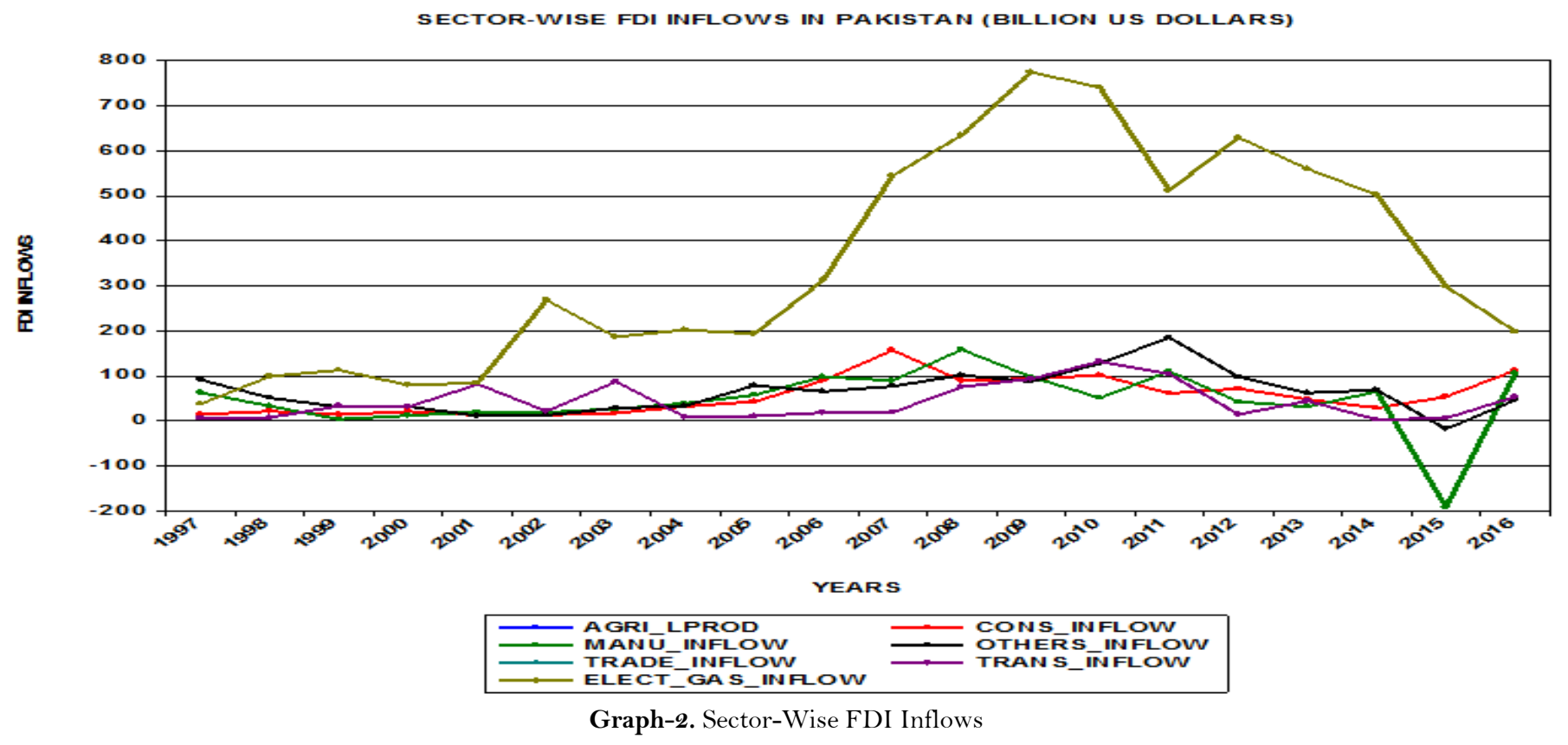

Table-3. Panel Unit Root Tests

\begin{tabular}{|c|c|c|c|c|c|c|c|c|c|}
\hline \multirow{3}{*}{$\begin{array}{l}\text { Method } \\
\text { Variables }\end{array}$} & \multicolumn{4}{|c|}{ Levin, Lin \& Chu } & \multicolumn{4}{|c|}{ Im, Pesaran and Shin (IPS) } & \multirow{3}{*}{\begin{tabular}{|l|}
$\begin{array}{l}\text { Order } \\
\text { Integration }\end{array}$ \\
\end{tabular}} \\
\hline & \multicolumn{2}{|l|}{ At Level } & \multicolumn{2}{|c|}{ At First Difference } & \multicolumn{2}{|l|}{ At Level } & \multicolumn{2}{|c|}{ At First Difference } & \\
\hline & Intercept & $\begin{array}{l}\text { Trend \& } \\
\text { Intercept }\end{array}$ & Intercept & $\begin{array}{l}\text { Trend \& } \\
\text { Intercept }\end{array}$ & Intercept & $\begin{array}{l}\text { Trend \& } \\
\text { Intercept }\end{array}$ & Intercept & $\begin{array}{l}\text { Trend \& } \\
\text { Intercept }\end{array}$ & \\
\hline LPROD & $\begin{array}{l}2.11491 \\
(0.9828) \\
\end{array}$ & $\begin{array}{l}1.52993^{*} \\
(0.0630)\end{array}$ & $\begin{array}{l}7.07647 * * * \\
(0.0000)\end{array}$ & $\begin{array}{l}5.74151^{* * * *} \\
(0.0000)\end{array}$ & $\begin{array}{l}3.18318 \\
(0.9999) \\
\end{array}$ & $\begin{array}{l}1.46509^{*} \\
(0.0714)\end{array}$ & $\begin{array}{l}7.70225^{* * * *} \\
(0.0000)\end{array}$ & $\begin{array}{l}\text { 6.25492*** } \\
(0.0000)\end{array}$ & $\mathrm{I}(1)$ \\
\hline INFLOW & $\begin{array}{l}1.34872 \\
(0.0887)\end{array}$ & $\begin{array}{l}0.1607 \\
(0.5652)\end{array}$ & $\begin{array}{l}4.42893^{* * * *} \\
(0.0000)\end{array}$ & $\begin{array}{l}3.91451^{* * * *} \\
(0.0000)\end{array}$ & $\begin{array}{l}2.31312^{*} \\
(0.0104)\end{array}$ & $\begin{array}{l}-0.95487 \\
(0.1698)\end{array}$ & $\begin{array}{l}5.75636^{* * * *} \\
(0.0000)\end{array}$ & $\begin{array}{l}4.77672^{*} * * \\
(0.0000)\end{array}$ & $\mathrm{I}(1)$ \\
\hline
\end{tabular}

Values in Parenthesis represent Probability values.

* significant at $10 \%$

** Significant at $5 \%$

**** Signiant at $1 \%$

Levin et al. (2002) has a null hypothesis of unit root which assumes a common unit root whereas, Im et al. (2003) also has the same null hypothesis but this test assumes individual unit root process. According to both tests, series are co-integrated of order 1, i.e., they become stationary at first difference (taking all significance level) which is a necessary condition for Cointegration test.

Before applying panel Cointegration test, it is required to check that which kind of static panel data model is appropriate.

\section{SECTION-3}

\section{1) Panel Data Models}

Three basic panel data models have been applied one by one along-with interpretations.

\section{(i) Pooled OLS}

Table-4. Pooled OLS (empirical results)

\begin{tabular}{|c|c|c|c|c|}
\hline \multicolumn{5}{|c|}{$\begin{array}{l}\text { Dependent Variable: LPROD } \\
\text { Method: Panel Least Squares } \\
\text { Assumption: All sectors are same (no individuality) }\end{array}$} \\
\hline \multicolumn{5}{|l|}{ Sample: 19972016} \\
\hline \multicolumn{5}{|l|}{ Periods included: 20} \\
\hline \multicolumn{5}{|c|}{ Cross-sections included: 7} \\
\hline \multicolumn{5}{|c|}{ Total panel (balanced) observations: 140} \\
\hline Variable & Coefficient & Std. Error & t-Statistic & Prob. \\
\hline $\mathrm{C}$ & 3102.485 & 327.0495 & 9.486287 & 0.0000 \\
\hline INFLOW & 9.191757 & 1.698498 & 5.411699 & 0.0000 \\
\hline R-squared & 0.175068 & \multicolumn{2}{|c|}{ Mean dependent var } & 4083.403 \\
\hline Adjusted R-squared & 0.169090 & \multicolumn{2}{|c|}{ S.D. dependent var } & 3533.585 \\
\hline S.E. of regression & 3221.013 & \multicolumn{2}{|c|}{ Akaike info criterion } & 19.00696 \\
\hline Sum squared resid & $1.43 \mathrm{E}+09$ & \multicolumn{2}{|c|}{ Schwarz criterion } & 19.04899 \\
\hline Log likelihood & -1328.487 & \multicolumn{2}{|c|}{ Hannan-Quinn criter. } & 19.02404 \\
\hline F-statistic & 29.28648 & \multicolumn{2}{|c|}{ Durbin-Watson stat } & 0.335267 \\
\hline Prob(F-statistic) & 0.000000 & \multicolumn{3}{|c|}{$\begin{array}{l}\text { DECISION: Inflow is significant but the assumption of } \\
\text { no individuality cannot be accepted }\end{array}$} \\
\hline
\end{tabular}

Although results are significant, yet this test is not preferred since it pools all seven sectors and denies the individuality. 


\section{(ii) Pooled OLS Vs Fixed effects (F-test)}

Now testing that which test is appropriate, fixed effect or pooled Regression Model? Also, is there any requirement for testing a model with heterogeneity? For this purpose, dummy variables are used to estimate fixed effect model. Since the panel consists of 7 sectors, 7 dummy variables are created. The equation to be estimated is

$\mathrm{LPROD}=\mathrm{C}(1)+\mathrm{C}(2) * \mathrm{INFLOW}+\mathrm{C}(3) * \mathrm{D} 1+\mathrm{C}(4) * \mathrm{D} 2+\mathrm{C}(5) * \mathrm{D} 3+\mathrm{C}(6) * \mathrm{D} 4+\mathrm{C}(7) * \mathrm{D} 5+\mathrm{C}(8) * \mathrm{D} 6+\mathrm{C}(9) * \mathrm{D} 7$

Where LPROD (sector-wise labor productivity) is the dependent variable and INFLOW (sector-wise FDI inflow) is the independent variable.

$\mathbf{C}(\mathbf{1})$ is the co-efficient of constant

$\mathbf{C}(\mathbf{2})$ is the co-efficient of INFLOW

$\mathrm{C}(3), \mathrm{C}(4), \mathrm{C}(5), \mathrm{C}(6), \mathrm{C}(7), \mathrm{C}(8)$ and $\mathrm{C}(9)$ are co-efficient of dummy 1, dummy2, dummy3, dummy4, dummy5, dummy 6 and dummy7 respectively.

The null and alternative hypothesis of Panel Least Square model are:

Null: Pooled regression model is appropriate (all dummy variables are zero)

Alternative: Fixed effect model is more appropriate (all dummy variables are not zero)

To check whether all dummy variables are zero or not, Wald test is used.

Table-5. Results of Wald Test (F-statistic)

\begin{tabular}{|c|c|c|c|}
\hline \multicolumn{4}{|l|}{$\begin{array}{l}\text { Wald Test: } \\
\text { F-statistic based test }\end{array}$} \\
\hline Test Statistic & Value & df & Probability \\
\hline F-statistic & 32.31158 & $(7,131)$ & 0.0000 \\
\hline Chi-square & 226.1811 & 7 & 0.0000 \\
\hline \multicolumn{4}{|c|}{$\begin{array}{l}\text { Null Hypothesis: } \mathbf{C}(3)=\mathbf{C}(4)=\mathbf{C}(5)=\mathbf{C}(6)=\mathbf{C}(7)=\mathbf{C}(8)=\mathbf{C}(9)=\mathbf{0} \\
\text { Null Hypothesis Summary: }\end{array}$} \\
\hline \multicolumn{2}{|c|}{ Normalized Restriction $(=0)$} & Value & Std. Err. \\
\hline \multicolumn{2}{|c|}{$\mathrm{C}(3)$} & -8072.629 & 2159.858 \\
\hline \multicolumn{2}{|c|}{$\mathrm{C}(4)$} & -5910.032 & 2175.133 \\
\hline \multicolumn{2}{|c|}{$\mathrm{C}(5)$} & -9262.234 & 2077.298 \\
\hline \multicolumn{2}{|c|}{$\mathrm{C}(6)$} & 22.57162 & 2055.820 \\
\hline \multicolumn{2}{|c|}{$\mathrm{C}(7)$} & -3533.529 & 2175.990 \\
\hline \multicolumn{2}{|c|}{$\mathrm{C}(8)$} & -6024.004 & 2173.176 \\
\hline \multicolumn{2}{|c|}{$\mathrm{C}(9)$} & -5055.283 & 2171.676 \\
\hline
\end{tabular}

Since the Probability value is almost zero, null hypothesis is rejected and alternative is accepted, i.e., Fixed effect model is appropriate according to F-Statistic model.

\section{(iii) Pooled Least-square Dummy variable Model}

Table-6. Results of Pooled LSDV Model (Fixed Effect)

\begin{tabular}{|c|c|c|c|c|}
\hline \multicolumn{5}{|c|}{ Dependent Variable: LPROD } \\
\hline \multicolumn{5}{|c|}{ Method: Panel Least Squares } \\
\hline \multicolumn{5}{|c|}{ Sample: 19972016} \\
\hline \multicolumn{5}{|l|}{ Periods included: 20} \\
\hline \multicolumn{5}{|c|}{ Cross-sections included: 7} \\
\hline \multicolumn{5}{|c|}{ Total panel (balanced) observations: 140} \\
\hline \multicolumn{5}{|c|}{$\mathrm{LPROD}=\mathrm{C}(1)+\mathrm{C}(2) * \mathrm{INFLOW}+\mathrm{C}(3)^{*} \mathrm{D} 1+\mathrm{C}(4) * \mathrm{D} 2+\mathrm{C}(5) * \mathrm{D} 3+\mathrm{C}(6) * \mathrm{D} 4+\mathrm{C}(7)$} \\
\hline \multicolumn{5}{|c|}{$* \mathrm{D} 5+\mathrm{C}(8) * \mathrm{D} 6+\mathrm{C}(9) * \mathrm{D} 7$} \\
\hline & Coefficient & Std. Error & t-Statistic & Prob. \\
\hline $\mathrm{C}(1)$ & 9317.984 & 2139.559 & 4.355097 & 0.0000 \\
\hline $\mathbf{C}(2)$ & 1.595601 & 1.378895 & 1.157159 & 0.2493 \\
\hline $\mathrm{C}(3)$ & -8072.629 & 2159.858 & -3.737574 & 0.0003 \\
\hline $\mathrm{C}(4)$ & -5910.032 & 2175.133 & -2.717090 & 0.0075 \\
\hline $\mathrm{C}(5)$ & -9262.234 & 2077.298 & -4.458790 & 0.0000 \\
\hline $\mathrm{C}(6)$ & 22.57162 & 2055.820 & 0.010979 & 0.9913 \\
\hline $\mathrm{C}(7)$ & -3533.529 & 2175.990 & -1.623872 & 0.1068 \\
\hline $\mathrm{C}(8)$ & -6024.004 & 2173.176 & -2.771982 & 0.0064 \\
\hline $\mathrm{C}(9)$ & -5055.283 & 2171.676 & -2.327826 & 0.0215 \\
\hline R-squared & 0.697447 & \multicolumn{2}{|c|}{ Mean dependent var } & 4083.403 \\
\hline Adjusted R-squared & 0.678971 & \multicolumn{2}{|c|}{ S.D. dependent var } & 3533.585 \\
\hline S.E. of regression & 2002.109 & \multicolumn{2}{|c|}{ Akaike info criterion } & 18.10392 \\
\hline Sum squared resid & $5.25 \mathrm{E}+08$ & \multicolumn{2}{|c|}{ Schwarz criterion } & 18.29302 \\
\hline Log likelihood & -1258.274 & \multicolumn{2}{|c|}{ Hannan-Quinn criter. } & 18.18076 \\
\hline F-statistic & 37.74779 & \multicolumn{2}{|c|}{ Durbin-Watson stat } & 0.551877 \\
\hline Prob(F-statistic) & 0.000000 & & & \\
\hline
\end{tabular}

Since LPROD is the dependent variable, the co-efficient of independent variable (INFLOW), which is C(2) must be same for fixed effect model estimation. The highlighted values in red show that in all tests the value of INFLOW co-efficient is same, which shows that it is fixed effect model.

\section{(iv) Fixed Effects or Random effects}

Now the question is that which test is more appropriate? To find out, Hausman test is applied. 
Table-7. Results of Hausman Test

\begin{tabular}{|c|c|c|c|c|}
\hline \multicolumn{4}{|c|}{ Correlated Random Effects - Hausman Test } & \\
\hline \multicolumn{4}{|c|}{ Test cross-section random effects } & \\
\hline Test Summary & & Chi-Sq. Statistic & Chi-Sq. d.f. & Prob. \\
\hline Cross-section random & & 4.017557 & 1 & 0.0450 \\
\hline \multicolumn{5}{|c|}{ Cross-section random effects test comparisons: } \\
\hline Variable & Fixed & Random & Var(Diff.) & Prob \\
\hline INFLOW & 1.596216 & 2.007554 & 0.042115 & 0.0450 \\
\hline
\end{tabular}

Prob. value is significant at 10 percent level, therefore it can be concluded that fixed effect Model is more appropriate.

DECISION: Both Hausman test and F-statistic suggest that Fixed Effect Model is appropriate.

\subsection{Panel Cointegration Tests}

Table-8. Results of Panel Cointegration test

Pedroni test with Individual intercepts

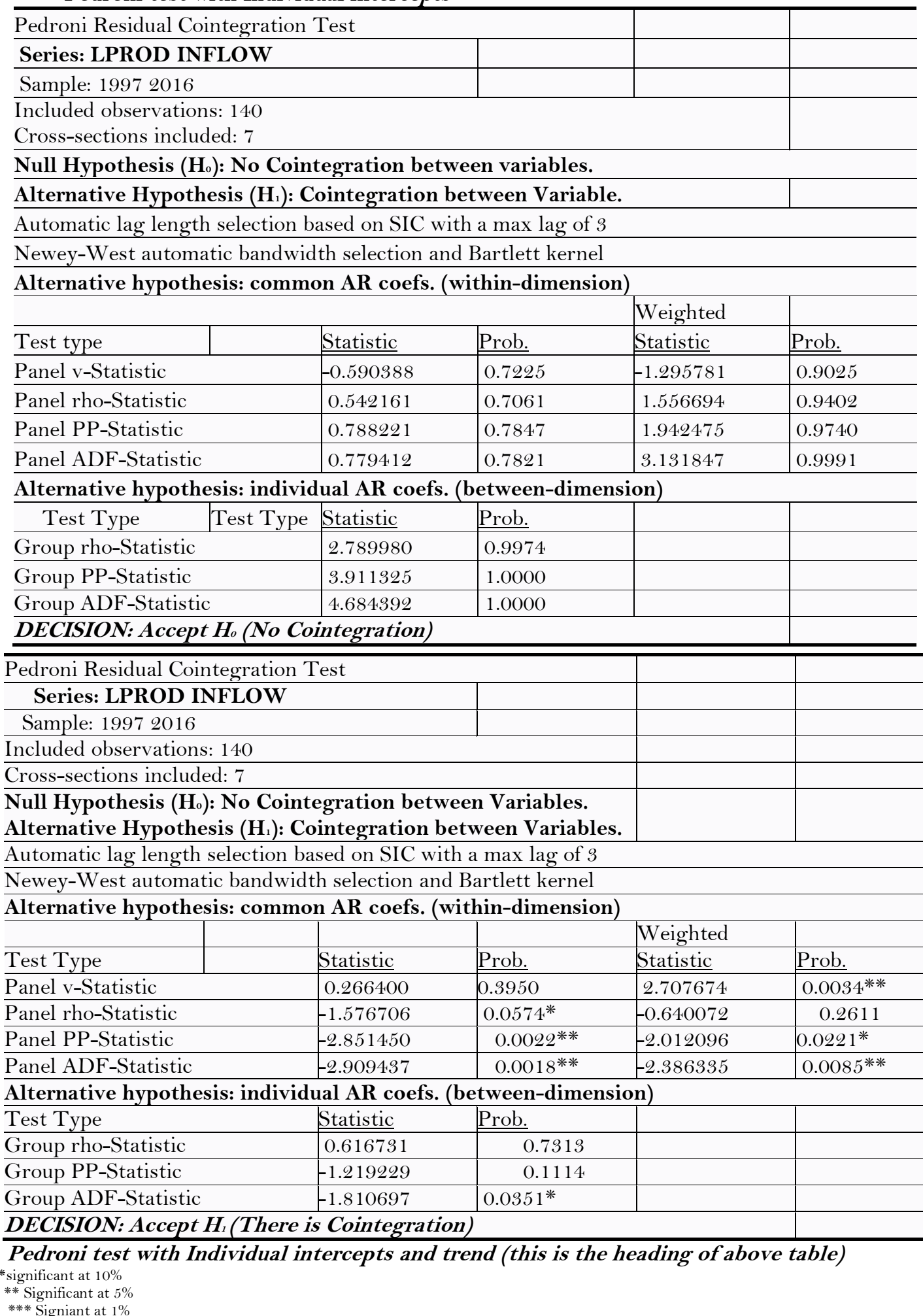

The results indicate that there is long run Cointegration between sector-wise labor productivity and sectorwise FDI inflows when test is carried out using both trend and intercept. Out of total 11 outcomes, 7 are significant, therefore, it is concluded that there is a strong evidence of Cointegration. For cross check, now applying Fisher Cointegration Test. 
Table-9. Johansen Fisher Panel Cointegration Test

- Johansen Fisher Panel Cointegration Test (empirical results)

\begin{tabular}{|c|c|c|c|c|}
\hline \multicolumn{5}{|c|}{ Series: LPROD INFLOW } \\
\hline \multicolumn{5}{|c|}{ Sample: 19972016} \\
\hline \multicolumn{5}{|c|}{ Included observations: 140} \\
\hline \multicolumn{5}{|c|}{ Trend assumption: Linear deterministic trend (restricted) } \\
\hline \multicolumn{5}{|c|}{ Lags interval (in first differences): 11} \\
\hline \multicolumn{5}{|c|}{ Unrestricted Cointegration Rank Test (Trace and Maximum Eigenvalue) } \\
\hline Hypothesized & Fisher Stat.* & & Fisher Stat.* & \\
\hline No. of $\mathrm{CE}(\mathrm{s})$ & (from trace test) & Prob. & (from max-eigen test) & Prob. \\
\hline None & 25.46 & 0.0303 & 27.92 & 0.0146 \\
\hline At most 1 & 9.371 & 0.8066 & 9.371 & 0.8066 \\
\hline \multicolumn{5}{|c|}{ * Probabilities are computed using asymptotic Chi-square distribution. } \\
\hline \multicolumn{5}{|c|}{ Individual cross section results } \\
\hline & Trace Test & & Max-Eign Test & \\
\hline Cross Section & Statistics & Prob.** & Statistics & Prob.** \\
\hline \multicolumn{5}{|c|}{ Hypothesis of no Cointegration } \\
\hline Agri & 23.2648 & 0.1020 & 15.9062 & 0.1493 \\
\hline manuf & 17.3666 & 0.3881 & 14.6940 & 0.2108 \\
\hline const & 21.7021 & 0.1515 & 16.9830 & 0.1080 \\
\hline$\overline{\mathrm{e} \& \mathrm{gg}}$ & 27.6196 & 0.0300 & 24.4816 & 0.0083 \\
\hline trans & 25.8957 & 0.0497 & 16.7830 & 0.1149 \\
\hline trade & 14.5430 & 0.6126 & 7.7133 & 0.8463 \\
\hline others & 15.4050 & 0.5410 & 13.1481 & 0.3162 \\
\hline \multicolumn{5}{|c|}{ Hypothesis of at most 1 cointegration relationship } \\
\hline Agri & 7.3587 & 0.3086 & 7.3587 & 0.3086 \\
\hline manuf & 2.6726 & 0.9130 & 2.6726 & 0.9130 \\
\hline const & 4.7191 & 0.6371 & 4.7191 & 0.6371 \\
\hline e\&g & 3.1380 & 0.8597 & 3.1380 & 0.8597 \\
\hline trans & 9.1128 & 0.1735 & 9.1128 & 0.1735 \\
\hline trade & 6.8297 & 0.3626 & 6.8297 & 0.3626 \\
\hline others & 2.2569 & 0.9508 & 2.2569 & 0.9508 \\
\hline
\end{tabular}

**MacKinnon (1990) p-values

Fisher test has a Null hypothesis that there is no co-integrated equation (the two variables are not cointegrated). In case of none, both trace test and max Eigen value test reject the null hypothesis. At the most one hypothesis has high probability values (more than $5 \%$ ) for both trace co-integrated and max Eigen value test which leads to the conclusion that there is Cointegration between two variables (sector wise labor productivity and sector wise FDI inflows are)

\subsection{Panel Vector Error Correction Model}

Although the basic model deals with LPROD being a dependent variable but for robustness of test, separate VECM and system equation model are estimated taking INFLOW as a dependent variable.

Table-10. Results of Panel Vector Error Correction Model (VECM) - $\quad$ when LPROD is dependent

\begin{tabular}{|c|c|c|}
\hline \multicolumn{3}{|c|}{$\begin{array}{l}\text { Vector Error Correction Estimates } \\
\text { Sample (adjusted): } 20002016 \\
\text { Standard errors in () \& t-statistics in }[]\end{array}$} \\
\hline Cointegrating Eq: & CointEq 1 & \\
\hline LPROD $(-1)$ & 1.000000 & \\
\hline INFLOW $(-1)$ & $\begin{array}{l}-74.83640 \\
(20.8250) \\
{[-\mathbf{3 . 5 9 3 5 9}]}\end{array}$ & \\
\hline$\overline{\mathrm{C}}$ & 4203.830 & \\
\hline Error Correction: & D(LPROD) & $\mathrm{D}$ (INFLOW) \\
\hline CointEq 1 & {$\left[\begin{array}{l}-0.039096 \\
(0.01282) \\
{[-\mathbf{3 . 0 5 0 3 5}]}\end{array}\right.$} & $\begin{array}{l}0.001254 \\
(0.00110) \\
{[\mathbf{1 . 1 4 4 5 0}]}\end{array}$ \\
\hline D(LPROD $(-1))$ & $\begin{array}{l}-0.245484 \\
(0.08641) \\
{[-\mathbf{2 . 8 4 0 8 0}]}\end{array}$ & {$\left[\begin{array}{l}-0.008062 \\
(0.00739) \\
{[-\mathbf{1 . 0 9 0 9 4}]}\end{array}\right.$} \\
\hline$\underline{\mathrm{D}(\operatorname{LPROD}(-2))}$ & $\begin{array}{l}-0.355847 \\
(0.08495) \\
{[-\mathbf{4 . 1 8 9 0 0}]}\end{array}$ & {$\left[\begin{array}{l}-0.005610 \\
(0.00726) \\
{[-\mathbf{0 . 7 7 2 2 1}]}\end{array}\right.$} \\
\hline D(INFLOW(-1)) & $\begin{array}{l}-3.756347 \\
(1.44851) \\
{[\mathbf{- 2 . 5 9 3 2 4}]}\end{array}$ & {$\left[\begin{array}{l}-0.471644 \\
(0.12388) \\
{[-3.80729]}\end{array}\right.$} \\
\hline D(INFLOW(-2)) & $\begin{array}{l}0.216792 \\
(1.39912) \\
{[\mathbf{0 . 1 5 4 9 5}]}\end{array}$ & $\begin{array}{l}-0.307120 \\
(0.11965) \\
{[-\mathbf{2 . 5 6 6 7 2}]}\end{array}$ \\
\hline
\end{tabular}




\begin{tabular}{l|l|l}
\hline & 351.5799 & 12.99057 \\
$\mathbf{C}$ & $(121.786)$ & $(10.4153)$ \\
{$[\mathbf{2 . 8 8 6 8 7}]$} & {$[\mathbf{1 . 2 4 7 2 6}]$} \\
\hline R-squared & 0.243475 & 0.210100 \\
\hline Adj. R-squared & 0.210001 & 0.175149 \\
\hline Sum sq. resids & $1.88 \mathrm{E}+08$ & 1376352. \\
\hline S.E. equation & 1290.479 & 110.3635 \\
\hline F-statistic & 7.273447 & 6.011222 \\
\hline Log likelihood & -1018.145 & -725.5252 \\
\hline Akaike AIC & 17.21252 & 12.29454 \\
\hline Schwarz SC & 17.35264 & 12.43466 \\
\hline Mean dependent & 231.6261 & 8.627731 \\
\hline S.D. dependent & 1451.903 & 121.5172 \\
\hline Determinant resid covariance (dof adj.) & $1.96 \mathrm{E}+10$ \\
\hline Determinant resid covariance & $1.76 \mathrm{E}+10$ \\
\hline Log likelihood & -1741.524 \\
\hline Akaike information criterion & 29.50460 \\
\hline Schwarz criterion & 29.83155 \\
\hline
\end{tabular}

The estimates of VECM also confirm a long run relationship between the variable under discussion. But the probability values are not available, for which system equation model is required. Since LPROD is the dependent variable, the first model is the main model of interest. VECM doesn't show probability values, therefore, construction of system equation model is required to get probability values.

Table-1 1. Results of System Equation Model

- Taking LPROD as dependent variable

\section{Estimation Method: Panel Least Squares}

Sample: 20002016

Included observations: 119

Total system (balanced) observations 238

Equation: D(LPROD) $=\mathrm{C}(1) *($ LPROD $(-1)-74.8363953179 * I N F L O W(-1)+$

4203.8300597 $)+\mathrm{C}(2) * \mathrm{D}(\operatorname{LPROD}(-1))+\mathrm{C}(3) * \mathrm{D}(\operatorname{LPROD}(-2))+\mathrm{C}(4)$

*D(INFLOW $(-1))+\mathbf{C}(5) * \mathrm{D}($ INFLOW $(-2))+\mathbf{C}(6)$

\begin{tabular}{|c|c|c|c|c|}
\hline & Coefficient & Std. Error & t-Statistic & Prob. \\
\hline $\mathrm{C}(1)$ & -0.039096 & 0.012817 & -3.050354 & 0.0026 ** \\
\hline $\mathrm{C}(2)$ & -0.245484 & 0.086414 & -2.840799 & $0.0049 * *$ \\
\hline $\mathrm{C}(3)$ & -0.355847 & 0.084948 & -4.188996 & 0.0000** \\
\hline $\mathrm{C}(4)$ & -3.756347 & 1.448514 & -2.593242 & $0.0101 *$ \\
\hline $\mathrm{C}(5)$ & 0.216792 & 1.399120 & 0.154949 & 0.8770 \\
\hline $\mathrm{C}(6)$ & 351.5799 & 121.7859 & 2.886868 & $0.0043 * *$ \\
\hline $\mathrm{C}(7)$ & 0.001254 & 0.001096 & 1.144501 & 0.2536 \\
\hline $\mathrm{C}(8)$ & -0.008062 & 0.007390 & -1.090941 & 0.2765 \\
\hline $\mathrm{C}(9)$ & -0.005610 & 0.007265 & -0.772207 & 0.4408 \\
\hline $\mathrm{C}(10)$ & -0.471644 & 0.123879 & -3.807294 & $0.0002 * *$ \\
\hline $\mathrm{C}(\mathbf{1 1})$ & -0.307120 & 0.119655 & -2.566724 & $0.0109 * *$ \\
\hline $\mathrm{C}(12)$ & 12.99057 & 10.41530 & 1.247258 & 0.2136 \\
\hline
\end{tabular}

Determinant residual covariance $1.76 \mathrm{E}+10$

Observations: 119

\begin{tabular}{l|l|l|l}
\hline R-squared & 0.243475 & Mean dependent var & 231.6261 \\
\hline Adjusted R-squared & 0.210001 & S.D. dependent var & 1451.903 \\
\hline S.E. of regression & 1290.479 & Sum squared resid & $1.88 \mathrm{E}+08$ \\
\hline Durbin-Watson stat & 2.162215 & &
\end{tabular}

Equation: D(INFLOW) = C(7)*( LPROD(-1) - 74.8363953179*INFLOW(-1) +

4203.8300597 $)+\mathrm{C}(8) * \mathrm{D}(\operatorname{LPROD}(-1))+\mathrm{C}(9) * \mathrm{D}(\operatorname{LPROD}(-2))+\mathrm{C}(10)$

*D(INFLOW $(-1))+\mathbf{C}(11) * \mathrm{D}($ INFLOW $(-2))+\mathbf{C}(12)$

Observations: 119

\begin{tabular}{l|l|l|l}
\hline R-squared & 0.210100 & Mean dependent var & 8.627731 \\
Adjusted R-squared & 0.175149 & S.D. dependent var & 121.5172 \\
\hline S.E. of regression & 110.3635 & & \\
Durbin-Watson stat & 1.828057 & Sum squared resid & 1376352. \\
\hline *Significant at 10\% &
\end{tabular}

*Significant at $10 \%$

** Significant at $5 \%$,

*** Signiant at $1 \%$

$\mathbf{C}(\mathbf{1})$ = Error Correction Term or speed of adjustment towards long run equilibrium

Since $\mathbf{C}(\mathbf{1})$ is negative and significant, it can be concluded that there is a long run causality running from independent variable (sector-wise FDI inflows) to dependent variable (sector-wise labor productivity). Or in simple words, an increase in sector specific FDI inflows leads to an increase in labor productivity working in that specific sector. This model explains long run causality which has already been established.

- When INFLOW is a dependent variable 
Table-12. Results of Panel Vector Error Correction Model (VECM)

\begin{tabular}{|c|c|c|}
\hline \multicolumn{3}{|c|}{ Vector Error Correction Estimates } \\
\hline \multicolumn{3}{|c|}{ Sample (adjusted): 20002016} \\
\hline \multicolumn{3}{|c|}{ Included observations: 119 after adjustments } \\
\hline \multicolumn{3}{|c|}{ Standard errors in ( ) \& t-statistics in [] } \\
\hline Cointegrating Eq: & CointEq 1 & \\
\hline \multirow{3}{*}{ INFLOW(-1) } & 1.000000 & \\
\hline & -0.013362 & \\
\hline & $(0.01282)$ & \\
\hline LPROD(-1) & {$[-1.04245]$} & \\
\hline$\overline{\mathbf{C}}$ & -56.17360 & \\
\hline \multirow[t]{3}{*}{ Error Correction: } & D(INFLOW) & D(LPROD) \\
\hline & -0.093882 & 2.925767 \\
\hline & $(0.08203)$ & $(0.95916)$ \\
\hline \multirow[t]{3}{*}{ CointEq1 } & {$[-1.14450]$} & {$[3.05035]$} \\
\hline & -0.471644 & -3.756347 \\
\hline & $(0.12388)$ & $(1.44851)$ \\
\hline \multirow[t]{3}{*}{ D(INFLOW(-1)) } & {$[-3.80729]$} & {$[-2.59324]$} \\
\hline & -0.307120 & 0.216792 \\
\hline & $(0.11965)$ & $(1.39912)$ \\
\hline \multirow[t]{3}{*}{ D(INFLOW(-2)) } & {$[-2.56672]$} & {$[0.15495]$} \\
\hline & -0.008062 & -0.245484 \\
\hline & $(0.00739)$ & $(0.08641)$ \\
\hline \multirow[t]{3}{*}{ D(LPROD(-1)) } & {$[-1.09094]$} & {$[-2.84080]$} \\
\hline & -0.005610 & -0.355847 \\
\hline & $(0.00726)$ & $(0.08495)$ \\
\hline \multirow[t]{3}{*}{ D(LPROD(-2)) } & {$[-0.77221]$} & {$[-4.18900]$} \\
\hline & 12.99057 & 351.5799 \\
\hline & $(10.4153)$ & $(121.786)$ \\
\hline$\overline{\mathbf{C}}$ & {$[1.24726]$} & {$[2.88687]$} \\
\hline R-squared & 0.210100 & 0.243475 \\
\hline Adj. R-squared & 0.175149 & 0.210001 \\
\hline Sum sq. resids & 1376352. & $1.88 \mathrm{E}+08$ \\
\hline S.E. equation & 110.3635 & 1290.479 \\
\hline F-statistic & 6.011222 & 7.273447 \\
\hline Log likelihood & -725.5252 & -1018.145 \\
\hline Akaike AIC & 12.29454 & 17.21252 \\
\hline Schwarz SC & 12.43466 & 17.35264 \\
\hline Mean dependent & 8.627731 & 231.6261 \\
\hline S.D. dependent & 121.5172 & 1451.903 \\
\hline \multicolumn{2}{|c|}{ Determinant resid covariance (dof adj.) } & $1.96 \mathrm{E}+10$ \\
\hline \multicolumn{2}{|c|}{ Determinant resid covariance } & $1.76 \mathrm{E}+10$ \\
\hline \multicolumn{2}{|l|}{ Log likelihood } & -1741.524 \\
\hline \multicolumn{2}{|c|}{ Akaike information criterion } & 29.50460 \\
\hline \multicolumn{2}{|l|}{ Schwarz criterion } & 29.83155 \\
\hline
\end{tabular}

Again constructing system equation model for obtaining probability values.

Table-13. Results of System Equation Model

\begin{tabular}{|c|c|c|c|c|}
\hline \multicolumn{5}{|c|}{$\begin{array}{l}\text { Estimation Method: Least Squares } \\
\text { Sample: } 20002016 \\
\text { Included observations: } 119 \\
\text { Total system (balanced) observations } 238\end{array}$} \\
\hline \multicolumn{5}{|c|}{$\begin{array}{l}\text { Equation: D(INFLOW) }=\text { C }(1) *(\text { INFLOW }(-1)-0.0133624821954 \\
\text { 56.1736043251 })+C(2) * D(I N F L O W(-1))+C(3) * D(I N F L O W(-2))+C(4) \\
* \text { D }(\text { LPROD }(-1))+C(5)^{*} \text { D }(\text { LPROD }(-2))+C(6)\end{array}$} \\
\hline & Coefficient & Std. Error & t-Statistic & Prob. \\
\hline $\mathrm{C}(1)$ & -0.093882 & 0.082028 & -1.144501 & 0.2536 \\
\hline $\mathrm{C}(2)$ & -0.471644 & 0.123879 & -3.807294 & $0.0002 * *$ \\
\hline $\mathrm{C}(3)$ & -0.307120 & 0.119655 & -2.566724 & $0.0109 *$ \\
\hline $\mathrm{C}(4)$ & -0.008062 & 0.007390 & -1.090941 & 0.2765 \\
\hline $\mathrm{C}(5)$ & -0.005610 & 0.007265 & -0.772207 & 0.4408 \\
\hline $\mathrm{C}(6)$ & 12.99057 & 10.41530 & 1.247258 & 0.2136 \\
\hline$C(7)$ & 2.925767 & 0.959157 & 3.050354 & $0.0026 * *$ \\
\hline $\mathrm{C}(8)$ & -3.756347 & 1.448514 & -2.593242 & 0.0101* \\
\hline $\mathrm{C}(9)$ & 0.216792 & 1.399120 & 0.154949 & 0.8770 \\
\hline$C(10)$ & -0.245484 & 0.086414 & -2.840799 & $0.0049 * *$ \\
\hline $\mathrm{C}(11)$ & -0.355847 & 0.084948 & -4.188996 & 0.0000**** \\
\hline $\mathrm{C}(12)$ & 351.5799 & 121.7859 & 2.886868 & 0.0043 \\
\hline \multicolumn{2}{|c|}{ Determinant residual covariance } & $1.76 \mathrm{E}+10$ & & \\
\hline \multicolumn{5}{|l|}{ Observations: 119} \\
\hline R-squared & 0.210100 & \multicolumn{2}{|c|}{ Mean dependent var } & 8.627731 \\
\hline Adjusted R-squared & 0.175149 & \multicolumn{2}{|c|}{ S.D. dependent var } & 121.5172 \\
\hline S.E. of regression & 110.3635 & \multicolumn{2}{|c|}{ Sum squared resid } & 1376352. \\
\hline
\end{tabular}




\begin{tabular}{|c|c|c|c|}
\hline Durbin-Watson stat & 1.828057 & & \\
\hline \multicolumn{4}{|c|}{$\begin{array}{l}\text { Equation: D(LPROD) }=\mathrm{C}(7) *(\text { INFLOW }(-1)-0.0133624821954 * \operatorname{LPROD}(-1)- \\
\text { 56.173604325 1 })+\mathrm{C}(8) * \mathrm{D}(\mathrm{INFLOW}(-1))+\mathrm{C}(9) * \mathrm{D}(\mathrm{INFLOW}(-2))+\mathrm{C}(10) \\
* \mathrm{D}(\operatorname{LPROD}(-1))+\mathrm{C}(11) * \mathrm{D}(\operatorname{LPROD}(-2))+\mathrm{C}(12) \\
\text { Observations: } 119\end{array}$} \\
\hline R-squared & 0.243475 & Mean dependent var & 231.6261 \\
\hline Adjusted R-squared & 0.210001 & S.D. dependent var & 1451.903 \\
\hline S.E. of regression & 1290.479 & Sum squared resid & $1.88 \mathrm{E}+08$ \\
\hline Durbin-Watson stat & 2.162215 & & \\
\hline
\end{tabular}

$\mathbf{C}(\mathbf{1})$ = Error Correction Term or speed of adjustment towards long run equilibrium

Since $\mathbf{C}(\mathbf{1})$ is negative though insignificant , it cannot be concluded that there is a long run causality running from dependent variable (sector-wise FDI inflows) to independent variable (sector-wise labor productivity). Therefore there is one way causality which is the main model i.e., sector -wise labor productivity is affected by sector-wise FDI inflows. Now checking short run causality through Wald Test.

\subsection{Wald Test}

- when LPROD is dependent

$\mathrm{C}(4)=$ coefficient of inflow $(-1)$

Table-14. Results of Panel Wald Test (estimating short-run causality)

$\mathrm{C}(5)=$ coefficient of inflow $(-2)$

Null Hypothesis states that $\mathrm{C}(4)=\mathrm{C}(5)=0$ which means that $\mathrm{C}(4)$ and $\mathrm{C}(5)$, jointly are zero.

\begin{tabular}{|c|c|c|c|}
\hline \multicolumn{4}{|l|}{ Wald Test: } \\
\hline Test Statistic & Value & $\mathrm{df}$ & Probability \\
\hline Chi-square & 9.551606 & 2 & 0.0084 \\
\hline \multicolumn{4}{|c|}{ Null Hypothesis: $C(4)=C(5)=0$} \\
\hline \multicolumn{4}{|c|}{ Normalized Restriction $(=0)$} \\
\hline & & Value & Std. Err. \\
\hline $\mathrm{C}(4)$ & & -3.756347 & 1.448514 \\
\hline $\mathrm{C}(5)$ & & 0.216792 & 1.399120 \\
\hline
\end{tabular}

Restrictions are linear in coefficients

Since the probability is less than 5 percent, Null hypothesis can be rejected. There exists a short run causality from independent variable (sector-wise FDI inflows) to dependent variable (sector-wise labor productivity)

- When INFLOW is a dependent variable

$\mathbf{C}(\mathbf{1 0})=$ coefficient of 1 PROD $(-1)$

$\mathbf{C}(\mathbf{1 1})=$ coefficient of $\operatorname{LPROD}(-2)$

Null Hypothesis states that $C(10)=C(11)=0$ which means that $C(10)$ and $C(11)$, jointly are zero.

Table-15. Results of Panel Wald Test (estimating short-run causality)

\begin{tabular}{|c|c|c|c|}
\hline \multicolumn{4}{|l|}{ Wald Test: } \\
\hline Test Statistic & Value & $\mathrm{df}$ & Probability \\
\hline Chi-square & 21.79722 & 2 & 0.0000 \\
\hline \multicolumn{4}{|c|}{$\begin{array}{l}\text { Null Hypothesis: } \mathbf{C}(\mathbf{1 0})=\mathbf{C}(\mathbf{1 1})=\mathbf{0} \\
\text { Null Hypothesis Summary: }\end{array}$} \\
\hline Normalized Restriction $(=0)$ & Value Std. Err. & & \\
\hline $\mathrm{C}(10)$ & & -0.245484 & 0.086414 \\
\hline $\mathrm{C}(11)$ & & -0.355847 & 0.084948 \\
\hline
\end{tabular}

In this case too, as the probability is less than 5 percent, Null hypothesis can be rejected. There exists a short run causality from independent variable (sector-wise labor productivity) to dependent variable (sector-wise FDIinflows).

The overall conclusion suggested by the empirical analysis proves that random effect or LSDV model is the most appropriate model for the data. Unit root tests suggest that all variables become stationary at first difference i.e., I (1). Pedroni and Fisher panel Cointegration models show that there exists a long run Cointegration between variables. The same is supported by VECM. System equation model shows that the independent variable has a long run causality on dependent variable, whereas, Wald test provides a strong evidence of short run causality between independent and dependent variables.

\section{SECTION- 4}

This section deals with an extended segment of empirical part based on spillover effects suggested in literature review. Some studies have suggested that there exists spillover effects in the form of one sector affecting the other; both in case of FDI inflows and labor productivity. For empirically testing spillover effects, pair-wise GrangerCausality test is applied. This part also adds further to the innovative contribution of the present study. Test has been carried out both at level and at first difference. 
Table-16._Pair Wise Granger-Causality Test at Level

\begin{tabular}{|c|c|c|c|}
\hline Direction Of Causality & F-Statistic & Prob. & Strength Of Causality \\
\hline AGRI_LPROD $\rightarrow$ AGRI_INFLOW & 6.80832 & $0.0095^{* *}$ & Strong Causality \\
\hline CONS_LPROD $\rightarrow$ AGRI_INFLOW & 16.9054 & $0.0002^{* *}$ & Strong Causality \\
\hline ELECT_GAS_LPROD $\rightarrow$ AGRI_INFLOW & 4.15488 & $0.0403^{*}$ & Weak Causality \\
\hline MANU_INFLOW $\rightarrow$ AGRI_INFLOW & 4.03740 & $0.0433^{*}$ & Weak Causality \\
\hline MANU_LPROD $\rightarrow$ AGRI_INFLOW & 5.91312 & $0.0149^{*}$ & Weak Causality \\
\hline OTHERS_INFLOW $\rightarrow$ AGRI_INFLOW & 7.42717 & $0.0071^{* *}$ & Strong Causality \\
\hline OTHERS_LPROD $\rightarrow$ AGRI_INFLOW & 8.85650 & $.0037 * *$ & Strong Causality \\
\hline TRADE_LPROD $\rightarrow$ AGRI_INFLOW & 3.80538 & $0.0500^{*}$ & Weak Causality \\
\hline AGRI_INFLOW $\rightarrow$ TRADE_LPROD & 3.14026 & $0.0772^{*}$ & Weak Causality \\
\hline TRANS_LPROD $\rightarrow$ AGRI_INFLOW & 3.80538 & $0.0500^{*}$ & Weak Causality \\
\hline AGRI_INFLOW $\rightarrow$ TRANS_LPROD & 3.14026 & $0.0772^{*}$ & Weak Causality \\
\hline AGRI_LPROD $\rightarrow$ CONS_INFLOW & 2.84937 & $0.0942^{*}$ & Weak Causality \\
\hline AGRI_LPROD $\rightarrow$ CONS_LPROD & 4.24308 & $0.0382^{*}$ & Weak Causality \\
\hline ELECT_GAS_INFLOW $\rightarrow$ AGRI_LPROD & 2.96506 & $0.0869^{*}$ & Weak Causality \\
\hline MANU_INFLOW $\rightarrow$ AGRI_LPROD & 3.59211 & $0.0573^{*}$ & Weak Causality \\
\hline AGRI_LPROD $\rightarrow$ MANU_INFLOW & 2.85021 & $0.0941^{*}$ & Weak Causality \\
\hline MANU_LPROD $\rightarrow$ AGRI_LPROD & 2.77625 & $0.0991 *$ & Weak Causality \\
\hline AGRI_LPROD $\rightarrow$ MANU_LPROD & 4.10974 & $0.0414^{*}$ & Weak Causality \\
\hline OTHERS_INFLOW $\rightarrow$ AGRI_LPROD & 7.18636 & $0.0079^{* *}$ & Strong Causality \\
\hline TRADE_LPROD $\rightarrow$ AGRI_LPROD & 4.11145 & $0.0413^{*}$ & Weak Causality \\
\hline TRANS_LPROD $\rightarrow$ AGRI_LPROD & 4.11145 & $0.0413 *$ & Weak Causality \\
\hline CONS_INFLOW $\rightarrow$ CONS_LPROD & 3.21053 & $0.0736^{*}$ & Weak Causality \\
\hline CONS_INFLOW $\rightarrow$ ELECT_GAS_INFLOW & 7.52173 & $0.0068 * *$ & Strong Causality \\
\hline CONS_INFLOW $\rightarrow$ MANU_INFLOW & 3.23694 & $0.0723 *$ & Weak Causality \\
\hline CONS_INFLOW $\rightarrow$ MANU_LPROD & 3.72899 & $0.0525^{*}$ & Weak Causality \\
\hline CONS_INFLOW $\rightarrow$ OTHERS_INFLOW & 4.44847 & $0.0337 *$ & Weak Causality \\
\hline OTHERS_LPROD $\rightarrow$ CONS_INFLOW & 9.90378 & $0.0024 * *$ & Strong Causality \\
\hline MANU_INFLOW $\rightarrow$ CONS_LPROD & 5.16748 & $0.0223 *$ & Weak Causality \\
\hline OTHERS_LPROD $\rightarrow$ CONS_LPROD & 9.94203 & $0.0024 * *$ & Weak Causality \\
\hline TRADE_LPROD $\rightarrow$ CONS_LPROD & 11.9232 & $0.0011^{* *}$ & Strong Causality \\
\hline TRANS_LPROD $\rightarrow$ CONS_LPROD & 11.9232 & $0.0011 * *$ & Strong Causality \\
\hline ELECT_GAS_INFLOW $\rightarrow$ ELECT_GAS_LPROD & 9.45353 & $0.0029 * *$ & Strong Causality \\
\hline MANU_INFLOW $\rightarrow$ ELECT_GAS_INFLOW & 4.26847 & $0.0376^{*}$ & Weak Causality \\
\hline ELECT_GAS_INFLOW $\rightarrow$ TRADE_INFLOW & 3.88697 & $0.0475^{*}$ & Weak Causality \\
\hline ELECT_GAS_INFLOW $\rightarrow$ TRANS_INFLOW & 3.88697 & $0.0475^{*}$ & Weak Causality \\
\hline ELECT_GAS_LPROD $\rightarrow$ OTHERS_INFLOW & 2.87770 & $0.0923^{*}$ & Weak Causality \\
\hline MANU_INFLOW $\rightarrow$ OTHERS_INFLOW & 8.17106 & $0.0050^{* *}$ & Strong Causality \\
\hline MANU_INFLOW $\rightarrow$ TRADE_INFLOW & 3.31218 & $0.0688^{*}$ & Weak Causality \\
\hline OTHERS_LPROD $\rightarrow$ MANU_LPROD & 4.75293 & $0.0282^{*}$ & Weak Causality \\
\hline TRADE_LPROD $\rightarrow$ MANU_LPROD & 7.16874 & $0.0080^{* *}$ & Strong Causality \\
\hline TRANS_LPROD $\rightarrow$ MANU_LPROD & 7.16874 & $0.0080^{* *}$ & Strong Causality \\
\hline OTHERS_INFLOW $\rightarrow$ OTHERS_LPROD & 4.86832 & $0.0264 *$ & Weak Causality \\
\hline TRADE_INFLOW $\rightarrow$ TRADE_LPROD & 3.45733 & $0.0625^{*}$ & Weak Causality \\
\hline TRADE_INFLOW $\rightarrow$ TRANS_LPROD & 3.45733 & $0.0625^{*}$ & Weak Causality \\
\hline TRANS_INFLOW $\rightarrow$ TRADE_LPROD & 3.45733 & $0.0625^{*}$ & Weak Causality \\
\hline TRANS_INFLOW $\rightarrow$ TRANS_LPROD & 3.45733 & $0.0625^{*}$ & Weak Causality \\
\hline
\end{tabular}

Significant at $10 \%$

** Significant at $5 \%$,

Test has been conducted using 2 Lags and 18 observations. Strong or weak causality is based on level of significance. $5 \%$ and $1 \%$ level represent strong causality where as $10 \%$ represents weak causality.

Table-17. Pair Wise Granger-Causality Test at First Difference

\begin{tabular}{l|c|c|c}
\hline Direction of Causality & F-Statistic & Prob. & Strength of Causality \\
\hline DCONS_LPROD $\rightarrow$ DAGRI_INFLOW & 4.61474 & $0.0326^{*}$ & Weak Causality \\
\hline DELECT_GAS_LPROD $\rightarrow$ DAGRI_INFLOW & 3.44244 & $0.0658^{*}$ & Weak Causality \\
\hline DAGRI_INFLOW $\rightarrow$ DMANU_LPROD & 8.54178 & $0.0049^{*} *$ & Strong Causality \\
\hline DOTHERS_INFLOW $\rightarrow$ DAGRI_INFLOW & 9.27609 & $0.0037^{*} *$ & Strong Causality \\
\hline DTRADE_INFLOW $\rightarrow$ DAGRI_INFLOW & 3.14080 & $0.0800^{*}$ & Weak Causality \\
\hline DAGRI_INFLOW $\rightarrow$ DTRADE_LPORD & 4.13372 & $0.0431^{*}$ & Weak Causality \\
\hline DTRANS_INFLOW $\rightarrow$ DAGRI_INFLOW & 3.14080 & $0.0800^{*}$ & Weak Causality \\
\hline DAGRI_INFLOW $\rightarrow$ DTRANS_LPROD & 4.13372 & $0.0431^{*}$ & Weak Causality \\
\hline DOTHERS_INFLOW $\rightarrow$ DAGRI_LPROD & 4.29300 & $0.0392^{*}$ & Weak Causality \\
\hline DCONS_INFLOW $\rightarrow$ DMANU_INFLOW & 7.53099 & $0.0076^{* *}$ & Strong Causality \\
\hline DCONS_INFLOW $\rightarrow$ DMANU_LPROD & 3.38722 & $0.0682^{*}$ & Weak Causality \\
\hline DOTHERS_LPROD $\rightarrow$ DCONS_INFLOW & 8.40304 & $0.0052^{*} *$ & Strong Causality \\
\hline DELECT_GAS $\rightarrow$ DCONS_LPROD & 3.67455 & $0.0569^{*}$ & Weak Causality \\
\hline DMANU_INFLOW $\rightarrow$ DCONS_LPROD & 4.27188 & $0.0397^{*}$ & Weak Causality
\end{tabular}




\begin{tabular}{l|c|c|l}
\hline DOTHERS_LPROD $\rightarrow$ DCONS_LPROD & 4.13602 & $0.0430^{*}$ & Weak Causality \\
\hline DTRADE_LPORD $\rightarrow$ DCONS_LPROD & 9.54526 & $0.0033^{*} *$ & Strong Causality \\
\hline DTRANS_LPROD $\rightarrow$ DCONS_LPROD & 9.5456 & $0.0033^{*} *$ & Strong Causality \\
\hline DELECT_GAS $\rightarrow$ DELECT_GAS_LPROD & 3.56908 & $0.0608^{*}$ & Weak Causality \\
\hline DMANU_INFLOW $\rightarrow$ DELECT_GAS & 3.61941 & $0.0589^{*}$ & Weak Causality \\
\hline DMANU_INFLOW $\rightarrow$ DELECT_GAS_LPROD & 4.64914 & $0.0320^{*}$ & Weak Causality \\
\hline DMANU_LPROD $\rightarrow$ DELECT_GAS_LPROD & 5.9376 & $0.0161^{*}$ & Weak Causality \\
\hline DMANU_INFLOW $\rightarrow$ DOTHERS_INFLOW & 2.93467 & $0.0917^{*}$ & Weak Causality \\
\hline DTRADE_LPORD $\rightarrow$ DMANU_LPROD & 3.13544 & $0.0803^{*}$ & Weak Causality \\
\hline DTRANS_LPROD $\rightarrow$ DMANU_LPROD & 3.13544 & $0.0803^{*}$ & Weak Causality
\end{tabular}

*Significant at $10 \%$

***ignificant at $5 \%$

*** Signiant at $1 \%$

Test has been conducted using 2 Lags and 18 observations

D represents Difference

Strong or weak causality is based on level of significance. $5 \%$ and $1 \%$ level represent strong causality where as $10 \%$ represents weak causality. inflows.

Granger-Causality test suggests existence of spillover effects both in case of labor productivity and FDI

\section{Interpretation of Empirical Results}

According to panel unit root tests, all series become stationary at first difference having same order of integration, i.e., I(1). Panel data models reveal that the most appropriate model is fixed effects models (LSDV). Same order of integration leads to application of Cointegration tests for checking long run relationship. For this purpose, Pedroni test and Johansen Fisher Panel Cointegration tests are applied. Evidence of Cointegration leads to application of Panel vector error correction model. For testing short-run relationship, Wald test is applied which shows that a uni-directional short-run causality exists running from sector-wise labor productivity to sector-wise FDI inflows. The pair-wise Granger-Causality test shows a broader picture, i.e., there exist spillover effects both in case of FDI inflows and labor productivity in all sectors, although in some cases, there is weak causality, yet it cannot be ignored.

\section{Conclusion and Policy Recommendations}

In this study, an empirical analysis has been carried out to analyze the relationship between sector-wise FDI inflows and respective sector-wise labor productivity in case of Pakistan. A panel of seven major sectors of economy has been made for which the results confirm that sector-wise FDI inflows increase respective sector-wise labor productivity. Moreover, the evidence of spillover effects from one sector to another have been found through Granger-Causality test.

Amongst the three sectors, agriculture is the most backward sector while industrial and services sectors (including their sub-sectors) attract more FDI inflows and consequently labor productivity of these sectors also increases on account of technology transfer, innovation and R \& D. However in comparison to industrial and services sectors, agriculture sector, on account of its inherent weaknesses caused by continuous fragmentation of land holdings, non-adoption of modern technologies due to lack of resources as well as awareness, does not attract substantial FDI and consequently remains deprived of higher labor productivity despite this sector's contribution of more than 21 percent to national GDP and absorption of 44 percent of entire labor force (Pakistan Economic Survey, 2015-16) Not only this, 66 percent of Pakistan's exports and major portion of services sector (transport, wholesale, trading etc.) are directly related to agriculture sector. Textile is the largest industrial sector of Pakistan and it is dependent on the cotton crop grown in the country and further textile products like yarn, fabrics, bed sheets, towels and garments etc. are related with cotton. Therefore, the Pakistani leadership has to accept agriculture to be the growth engine for the economic development of Pakistan and prosperity of its people and to invest more, both internally as well as through international resources for not only increasing the average per acre yield but also to enhance the productivity of the labor employed in this sector. Pakistan has to transform its agriculture, presently at the subsistence level, to suit the requirements of market economy.

\section{References}

Adnan, Z., M.B. Chowdhury and G. Mallik, 2017. Foreign direct investment and its impact on total factor productivity in Pakistan. (M. A. Rahman, A. Ahmed, M. Ashraf, \& M. Chowdhury, Eds.). Proceedings of the 1st International Conference on Business Research and Ethics (iCBRE), 20-22 November, 2017, Sydney, Australia. pp: 29-38.

Alam, A., C.P. Anós, F. Khan and C. Udomsaph, 2008. Unleashing prosperity: Productivity growth in Eastern Europe and the former soviet union. Washington, DC: World Bank. (C) World Bank. License: Creative Commons Attribution CC BY 3.0 IGO. Retrieved: https://openknowledge.worldbank.org/handle/10986/6588.

Alam, A., M.U. Arshad and W. Rajput, 2013. Relationship of labor productivity, foreign direct investment and economic growth: Evidence from OECD countries. Journal of Business and Management Sciences, 1(6): 133-138. View at Google Scholar

Azeroual, M., 2016. The impact of foreign direct investment on the productivity growth in the Moroccan manufacturing sector: Is source of FDI important? Azeroual, Journal of International and Global Economic Studies, 9(1): 29-45. View at Google Scholar

Bang, T., V.B. Gangnes and I. Noy, 2007. Is foreign direct investment good for growth? Evidence from sectoral analysis of China and Vietnam. SCCIE Working Paper No.07-17. Retrieved from https://openknowledge.worldbank.org/handle/10986/6588.

Bijsterbosch, M. and M. Kolasa, 2010. FDI and productivity convergence in Central and Eastern Europe: An industry-level investigation. Review of World Economics, 145(4): 689-712. View at Google Scholar | View at Publisher

Contessi, S. and A. Weinberger, 2009. Foreign direct investment, productivity, and country growth: An overview. Federal Reserve Bank of St. Louis Review, 91(2): 61-78. View at Google Scholar

Dürnel, J.C., 2012. The effects of foreign direct investment on Turkish economy. Master's Thesis. Lund University, School of Economics and Management

Sciences: $1-69$ Retrieved

from http://lup.lub.lu.se/luur/download?func=downloadFile\&recordOId=3046743\&fileOId=3051251 
Fillat, C. and J. Woerz, 2011. Good or bad? The influence of FDI on productivity growth. An industry-level analysis. Journal of International Trade \& Economic Development, 20(3): 293-328. View at Google Scholar $\mid$ View at Publisher

Ilboudo, P.S., 2014. Foreign direct investment and total factor productivity in the mining sector: The case of Chile. Economics Honors Papers, Paper 18. Connecticut College, New London, Connecticut, 1-109. Retrieved from https://pdfs.semanticscholar.org/aea8/39ad18c51d104ff85def2985504ede082b77.pdf.

Im, K.S., M.H. Pesaran and Y. Shin, 2003. Testing for unit roots in heterogeneous panels. Journal of Econometrics, 115(1): 53-74. View at Google Scholar | View at Publisher

Johnson, A., 2005. Host country effects of foreign direct investment: The case of developing and transition economies. Doctoral Dissertation, Jönköping International Business School.

Kasi, N. and M. Zafar, 2016. Horizontal and Vertical spillover effects on sectoral productivity in selected SAARC country. S3 H Working Paper Series NUST, Islamabad. School of Social Sciences and Humanity, Number 08:2016, 1-45. Retrieved from https://www.coursehero.com/file/23828365/Noreen-08-16/.

Khan, M.A., 2011. Foreign direct investment in Pakistan: The role of international political relations. TMD Working Paper Series No. 039, Department of Politcal and International Relations, University of Oxford, ISSN, 2045-5119. 1-59. Retrieved from http://www.oxfordtmcd.org/sites/www.tmd-oxford.org/files/SLPTMD-WP-039.pdf.

Khan, M.A. and S.A. Khan, 2011. Foreign direct investment and economic growth in Pakistan: A sectoral analysis. Working Papers \& Research Reports.

Kirti, R. and S. Prasad, 2016. FDI impact on employment generation and GDP growth in India. Asian Journal of Economics and Empirical Research, 3(1): 40-48. View at Google Scholar | View at Publisher

Kurtishi-Kastrati, S., 2013. The effects of foreign direct investments for host country's economy. European Journal of Interdisciplinary Studies, 5(1): 26-38. View at Google Scholar

Levin, A., C.F. Lin and C.S.J. Chu, 2002. Unit root tests in panel data: Asymptotic and finite-sample properties. Journal of Econometrics, 108(1): 1-24. View at Google Scholar $\mid$ View at Publisher

Maathai, K.M. and D. Sahoo, 2008. Do foreign direct investment inflows benefit the major sectors in India? ISAS Working Paper No. 38, National University of Singapore, 1-25. Retrieved from http://citeseerx.ist.psu.edu/viewdoc/summary?doi=10.1.1.604.7711.

MacKinnon, J.G., 1990. Critical values for cointegration tests. San Diego: Department of Economics, University of California. pp: 267.

Mallick, J., 2013. Globalization and labor productivity in OECD regions. Faculty of Economics and Administration, Paper Prepared for "Regional Development Conference" May.

Mallick, J., 2015. Globalisation, structural change and labor productivity growth in BRICS Economy (No. 141). FIW Working Paper.

Morrar, R. and F. Gallouj, 2016. The growth of the service sector in Palestine: The productivity challenge. Journal of Innovation Economics \& Management, 19(1): 179-204. View at Google Scholar | View at Publisher

Msuya, E., 2007. The impact of foreign direct investment on agricultural productivity and poverty reduction in Tanzania. Munich Personal RePEc Archive, 1-15. Available from https://mpra.ub.uni-muenchen.de/id/eprint/3671.

Pakistan Economic Survey, 2015-16. Ministry of finance, government of Pakistan. Retrieved from http://www.finance.gov.pk/survey/chapters_16/02_Agriculture.pdf [Accessed July, 15th, 2017].

Park, D. and K. Shin, 2012. The service sector in Asia: Is it an engine of growth? Asian Development Bank Working Paper Series No. 322, 135. Retrieved from https://papers.ssrn.com/sol3/papers.cfm?abstract_id=2198154.

Sahoo, P., 2006. Foreign direct investment in South Asia: Policy, trends, impact and determinants (No. 56). ADB Institute Discussion Papers.

Serfraz, A., 2017. Analyzing short-run and long-run causality between FDI flows, labour productivity and education in Pakistan (No. 61). Discussion Papers, Zentrum für Ökonomische und Soziologische Studien.

Slimane, M.B., M. Huchet-Bourdon and H. Zitouna, 2013. Direct and indirect effects of FDI on food security: A sectoral approach. Workshop MAD Macroeconomics of Agriculture and Develoment-What Challenges Food Security? pp: 27.

Suleman, M.T. and M.T. Amin, 2015. The impact of sectoral foreign direct investment on industrial economic growth of Pakistan. Journal of Management Sciences, 2(1): 102-123. View at Google Scholar

Thangavelu, S.M., L.Y. Ing and S. Urata, 2015. Services productivity and trade openness: Case of ASEAN. ERIA Discussion Paper, No. 56.

Thuy, L.T., 2007. Does foreign direct investment have an impact on the growth in labor productivity of Vietnamese domestic firms? Hanoi, Vietnam: Faculty of International Economics and Business, Hanoi Foreign Trade University.

Ullah, A., M.U. Khan, S. Ali and S.W. Hussain, 2012. Foreign direct investment and sectoral growth of Pakistan economy: Evidence from agricultural and industrial sector (1979 to 2009). African Journal of Business Management, 6(26): 7816. View at Google Scholar | View at Publisher

Vu, T.B. and I. Noy, 2009. Sectoral analysis of foreign direct investment and growth in the developed countries. Journal of International Financial Markets, Institutions and Money, 19(2): 402-413. View at Google Scholar

Yusuf, S., 2013. Can Chinese FDI accelerate Pakistan's growth?. Working Paper. International Growth Centre, 4: 1-46. View at Google Scholar 